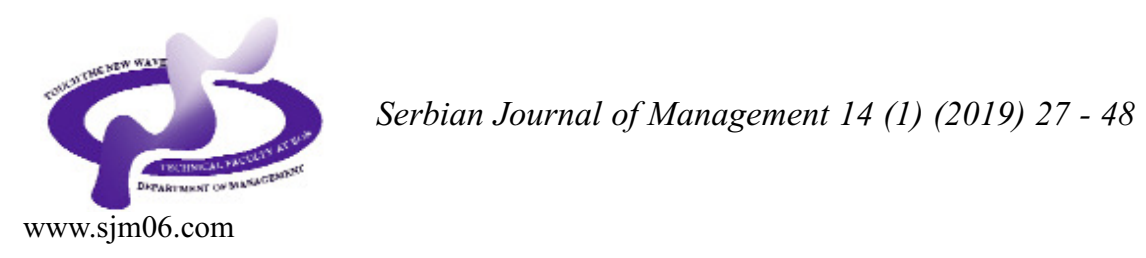

\title{
MENU EVALUATION BASED ON ROUGH MAIRCA AND BW METHODS
}

\author{
Slaviša N. Arsića ${ }^{\text {a*}}$, Dragan Pamučar ${ }^{a}$, Milija Suknović ${ }^{b}$ and Miljojko Janoševićc

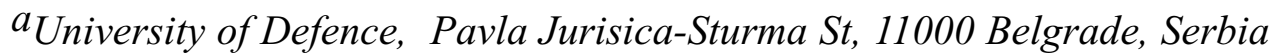 \\ $b_{\text {University of Belgrade, Faculty of Organizational Sciences, }}$ \\ Jove Ilića 154, 11000 Belgrade, Serbia \\ ${ }^{c}$ Military Medical Academy, 17 Crnotravska St., 11040 Belgrade, Serbia
}

(Recieved 31 August 2018; accepted 12 February 2019)

\begin{abstract}
The evaluation of dishes represents basic activity in the structuring of menu, which allows the optimal use of resources in order to fully satisfy the expectations of users and restaurant management.

This study presents a new approach in menu evaluation using the MultiAttributive Ideal-Real Comparative Analysis (MAIRCA) method, modified by application of rough numbers in dealing with imprecisions in group decision making and the Best-Worst Method (BWM) for determining the interval values of weight coefficients which objectivize the inconsistencies in expert judgment.

The model was successfully tested on the menu of a collective nutrition restaurant, where the evaluation of six existing breakfast dishes and a new dish that should replace the worst ranking dish was carried out.

Validation of the model was done by comparing the results obtained by application of MABAC and VIKOR methods, which confirmed high reliability. The validated values were discussed in sensitivity analysis, through 27 scenarios with the change in value of weight coefficients, which showed a large correlation of the obtained ranks and confirmed credibility of the obtained values.
\end{abstract}

Keywords: menu evaluation, restaurant management, rough MAIRCA, BWM, collective nutrition

\section{INTRODUCTION}

A high-quality menu allows optimal utilization of capacity and resources of a restaurant in order to fully satisfy the expectations of users and restaurant management. The menu represents a worthwhile synthesis of the target group of

*Corresponding author: arsic.slavisa@gmail.com

DOI: $10.5937 /$ sjm14-18736 
users' needs, on one hand, and the ability of a restaurant to prepare a dish in a costeffective way according to defined standards, on the other. The menu is structured based on the production capacities of a restaurant (technical, technological and organizational), available resources and the preferences of a restaurant service users.

In the process of menu optimization, the evaluation of dishes presents a basic activity by which the dishes with lesser performance and a smaller contribution to the set goals are innovated or substituted with better ones. All business decisions of restaurants related to production and placement are derived from the menu. (Taylor \& Brown, 2007). The menu interprets to the guest restaurant's offer, hospitality, and a type of service and influences the creation of a unique experience in dining (McCall \& Lyn, 2008). For this reason, researchers in many studies are working to create a model for menu optimization to increase efficiency, customer satisfaction and profit (Taylor et al., 2009).

Models for menu analysis allow systematic evaluation by comparing individual dishes according to previously selected criteria. Earlier approaches in menu evaluation were focused on the contribution margin of food cost and the popularity of product-mix.

The first menu analysis was carried out by Miller, using a four-quadrant matrix in which over the vectors, associated with the popularity of dishes and the level of sales, he monitored the value he defined as the sales velocity (Miller, 1980). Kasawana and Smith, using the Boston Consulting Group Portfolio Analysis as the basis for "Menu Engineering Matrix approach", included in the analysis product profitability (by measuring contribution margin), excluding the possibility of interdependence of low food costs and high gross profit (Kasawana \& Smith, 1982). Pavesic noticed the correlation of low food costs and high gross profit and instead of a gross profit item included in the analysis a weighted ratio of gross profit / contribution margin. Pavesic also treated the "popularity of dishes" as an indirect third variable (Pavesic, 1983). Hayes and Huffman by analyzing profits and losses tried to allocate all costs, including labor and fixed costs, to individual dishes in the menu (Hayes \& Huffman, 1985). Miller later developed a matrix model for the analysis of menu profitability through the cost of food and product mix without considering the costs of products (Miller, 1987).

Bayou and Bennet designed the profitability analysis model and tried to allocate variable costs, such as labor, to evaluate the financial power of each meal (Bayou \& Bennett, 1992). Le Bruto, Quain and Ashley modified "Kasawana and Smith Model" (KSM) trying to allocate labor costs, a separately fixed and variable component, to each dish in the menu (LeBruto et al., 1995). The lack of all matrixmodels lies in the assumption that indirect costs are equally allocated to all menu items (Morrison, 1996). In order to overcome the limitations of twodimensional matrix Cohen, Mesica and Schwarz included five factors in the analysis of menu dishes (food costs, price, labor costs, popularity and contribution margin) and normalization of the input data value into scalar variables ranging from 1-10 (Cohen et al., 1998). This approach did not consider other factors of production and did not give the explanation to how labor costs are measured. Horton modified KSM by including the value of "estimated labor" in contribution margin (gross profit) (Horton, 2001). Taylor, Reynolds, and Brown presented a non-parametric statistical 
approach that remedied the deficiencies of earlier models related to measuring of labor and the analysis of used data (Taylor et al., 2009).

Tom and Annaraud treated the imprecision in evaluation of alternatives by means of linguistic variables using the "fuzzy" technique in KSM, thereby contributed to acquiring relevant information for decision maker in multi-criteria decisionmaking (MCDM) (Tom \& Annaraud, 2017).

Previous research did not sufficiently exploit the benefits of MCDM method and decision support tools, which give the decision maker an opportunity to aggregate a wide range of relevant criteria for menu evaluation. The new approach allows optimization of menu assortment through innovation of existing dishes and replacement of low-ranking ones in the menu with new and better-quality dishes.

This study presents a new approach in the evaluation of menu dishes using rough numbers (rough numbers - RN) in Multi Attributive Ideal Real Comparative Analysis (MAIRCA) Model, and interval values of weight coefficients in the Best-Worst Method (BWM). By modifying the traditional MAIRCA model using rough numbers, the imprecisions in group decisionmaking, through use of interval values (rough numbers), are taken into consideration. In addition, the application of interval numbers objectivizes the values of weight coefficients through recognition of imprecisions that exists in the data. The presented approach enables precise menu evaluation, based on quantitative and qualitative criteria with concrete numerical indicators for each alternative, and favoring the selected criteria depending on the evaluation objectives and the context in which it is carried out.
The first goal of the study is to define relevant criteria for multi-criteria menu evaluation based on the selected literature and expert experience. The second objective is to define an adequate model for assessing the weights of criteria. The third goal is to profile multi-criteria model for evaluation and ranking of dishes in the menu. The fourth goal is to show the use of rough numbers for exploitation of imprecisions in the menu evaluation multi-criteria model.

The rest of the study is organized in the following way. In the second chapter, the algorithm of hybrid BWM-R'MAIRCA model is presented, which is later tested in the third chapter on a real example, the evaluation of a university restaurant menu. The fourth chapter presents a discussion of BWM-R'MAIRCA model results. The discussion of results was carried out through sensitivity analysis and the comparison of results with "rough" extensions of MABAC and VIKOR models. Finally, chapter five presents concluding observations with a special emphasis on directions of future research.

\section{MULTI-CRITERION BWM- R'MAIRCA MODEL}

Multi-criterion BWM-R'MAIRCA model is realized through two phases: (1) determining the weight coefficients of evaluation criteria and (2) the evaluation of alternatives (in the menu). BWM was used to determine the weight coefficients of criteria. After the application of BWM, in the second phase of MCDM model for alternative evaluation, the original modification of MAIRCA method (Pamučar et al., 2014) based on rough approach is used. The authors have chosen to apply MAIRCA 
method due to many recommended advantages: (1) mathematical framework of the method remains the same regardless of the number of alternatives and criteria; (2) possibility of application in case of a larger number of alternatives and criteria; (3) clearly defined alternative rank that is expressed in numerical value, which enables easier understanding of the results; (4) it is applicable to qualitative and quantitative type of criteria, and (5) gives objective ranks depending on the predefined dominance threshold (Gigović et al., 2016; Badi \& Ballem, 2018). In the following section, the application algorithm of BWM and R'MAIRCA methods is presented in detail.

\subsection{Rough numbers and aggregators}

In group decision making involving a large number of experts, there is a problem of aggregating expert decisions, defining priorities from aggregated decisions, and the problem of processing the imprecision found in expert preferences.

The concept of rough numbers introduced by Zhai (Zhai et al., 2008) was derived from the theory of rough sets (Pavlak, 1982), in order to process the subjective assessments of respondents and determine the intervals of their assessments. If there are differences in preferences in the aggregation of expert estimates, the obtained preferences are presented as interval or rough numbers. Greater differences in preferences mean greater data inaccuracy, resulting in larger intervals of rough numbers. In the event of no imprecision, that is, if all the experts assign the same preferences to the observed object, then the preferences are not shown by interval numbers but by "crisp" numbers. Rough numbers consist of a lower boundary, an upper boundary, and a boundary interval
(Vasiljevic et al., 2018). The above elements of rough numbers are based on the original data collected from the respondents. This means that for the definition of a rough number no additional information is required, which can impair the quality of the existing data with its subjectivity. In this way, the perceptions of respondents (experts) who express their decisions in an objective manner are acquired which additionally improves the objectivity of decision-making process.

For the purpose of aggregation of expert decisions in this study, a rough geometric Bonferroni operator (GBM) was constructed. In GBM execution process, rough numbers are used, which is why in the following section basic arithmetic operations with rough numbers are shown. Since rough numbers belong to a group of interval numbers, the arithmetic operations that apply to interval numbers also apply to rough numbers.

Definition 1. Let $\phi_{1}$ and $\phi_{2}$ be rough numbers defined as $R N\left(\phi_{1}\right)=\left[\underline{\operatorname{Lim}}\left(\phi_{1}\right), \overline{\operatorname{Lim}}\left(\phi_{1}\right)\right]$ and $R N\left(\phi_{2}\right)=\left[\underline{\operatorname{Lim}}\left(\phi_{2}\right), \overline{\operatorname{Lim}}\left(\phi_{2}\right)\right] \quad$ and $k$ the constant for which it is $k>0$, then the arithmetic operations with $\mathrm{RN}\left(\phi_{1}\right), \mathrm{RN}\left(\phi_{2}\right)$, and $k$ are performed in the following way (Zhu et al., 2015):

(1) Addition of rough numbers"+"

$$
\begin{aligned}
& R N\left(\phi_{1}\right)+R N\left(\phi_{2}\right) \\
& =\left[\underline{\operatorname{Lim}}\left(\phi_{1}\right), \overline{\operatorname{Lim}}\left(\phi_{1}\right)\right]+\left[\underline{\operatorname{Lim}}\left(\phi_{2}\right), \overline{\operatorname{Lim}}\left(\phi_{2}\right)\right] \\
& =\left[\underline{\operatorname{Lim}}\left(\phi_{1}\right)+\underline{\operatorname{Lim}}\left(\phi_{2}\right), \overline{\operatorname{Lim}}\left(\phi_{1}\right)+\overline{\operatorname{Lim}}\left(\phi_{2}\right)\right]
\end{aligned}
$$

(2) Subtraction of rough numbers"-"

$$
\begin{aligned}
& R N\left(\phi_{1}\right)-R N\left(\phi_{2}\right) \\
& =\left[\underline{\operatorname{Lim}}\left(\phi_{1}\right), \overline{\operatorname{Lim}}\left(\phi_{1}\right)\right]-\left[\underline{\operatorname{Lim}}\left(\phi_{2}\right), \overline{\operatorname{Lim}}\left(\phi_{2}\right)\right] \\
& =\left[\underline{\operatorname{Lim}}\left(\phi_{1}\right)-\overline{\operatorname{Lim}}\left(\phi_{2}\right), \overline{\operatorname{Lim}}\left(\phi_{1}\right)-\underline{\operatorname{Lim}}\left(\phi_{2}\right)\right]
\end{aligned}
$$


(3) Multiplication of rough numbers" $\times$ " $R N\left(\phi_{1}\right) \times R N\left(\phi_{2}\right)$

$=\left[\underline{\operatorname{Lim}}\left(\phi_{1}\right), \overline{\operatorname{Lim}}\left(\phi_{1}\right)\right] \times\left[\underline{\operatorname{Lim}}\left(\phi_{2}\right), \overline{\operatorname{Lim}}\left(\phi_{2}\right)\right]$

$=\left[\underline{\operatorname{Lim}}\left(\phi_{1}\right) \times \underline{\operatorname{Lim}}\left(\phi_{2}\right), \overline{\operatorname{Lim}}\left(\phi_{1}\right) \times \overline{\operatorname{Lim}}\left(\phi_{2}\right)\right]$

(4) Division of rough numbers"/"

$R N\left(\phi_{1}\right) / R N\left(\phi_{2}\right)$

$=\left[\underline{\operatorname{Lim}}\left(\phi_{1}\right), \overline{\operatorname{Lim}}\left(\phi_{1}\right)\right] /\left[\underline{\operatorname{Lim}}\left(\phi_{2}\right), \overline{\operatorname{Lim}}\left(\phi_{2}\right)\right]$

$=\left[\underline{\operatorname{Lim}}\left(\phi_{1}\right) / \overline{\operatorname{Lim}}\left(\phi_{2}\right), \overline{\operatorname{Lim}}\left(\phi_{1}\right) / \underline{\operatorname{Lim}}\left(\phi_{2}\right)\right]$

(5) Scalar multiplication of rough numbers where $k>0$

$k \times R N\left(\phi_{1}\right)=k \times\left[\underline{\operatorname{Lim}}\left(\phi_{1}\right), \overline{\operatorname{Lim}}\left(\phi_{1}\right)\right]$

$=\left[k \times \operatorname{Lim}\left(\phi_{1}\right), k \times \overline{\operatorname{Lim}}\left(\phi_{1}\right)\right]$

Definition 2. Let $\left(a_{1}, a_{2}, \ldots, a_{n}\right)$ be a set of non-negative numbers, the function GBM: $R^{n} \rightarrow R, w_{i}(i=1,2, \ldots, n)$ be the relative weight of ai $(i=1,2, \ldots, n), w_{i} \in[0,1]$ and $\sum_{i=1}^{n} w_{i}=.1$

If $p, q \geq 0$ and GBM satisfies:

$\operatorname{GBM}^{p, q}\left(a_{1}, a_{2}, \ldots, a_{n}\right)=\left(\frac{1}{n} \sum_{i, j=1}^{n} a_{i}^{p}\left(\prod_{j=1}^{n} a_{j}^{q}\right)^{\frac{1}{n-1}}\right)^{\frac{1}{p+q}}$

then GBMp,q is called a geometric BM operator (Zhu et al., 2012).

Definition 3. Set $R N\left(\phi_{i}\right)=\left[\underline{\operatorname{Lim}}\left(\phi_{i}\right), \overline{\operatorname{Lim}}\left(\phi_{i}\right)\right]$ $(i=1,2, \ldots, n)$ as a collection of RNs in $\Theta$, then RNGBM can be defined as follows $\operatorname{RNGBM}^{p, q}\left(R N\left(\phi_{1}\right), R N\left(\phi_{2}\right), \ldots, R N\left(\phi_{n}\right)\right)$

$=\left(\frac{1}{n} \sum_{\substack{i, j=1 \\ i \neq j}}^{n} R N\left(\phi_{i}^{p}\right)\left(\prod_{j=1}^{n} R N\left(\phi_{j}^{q}\right)\right)^{\frac{1}{n-1}}\right)^{\frac{1}{p+q}}$

and then RNGBMp,q is called a rough number geometric BM operator.

According to Definition 1 and Definition 3 , the following theorem is obtained:
Theorem 1. Set $R N\left(\phi_{i}\right)=\left[\underline{\operatorname{Lim}}\left(\phi_{i}\right), \overline{\operatorname{Lim}}\left(\phi_{i}\right)\right]$ $(i=1,2, \ldots, n)$ as a collection of RNs in $\Theta$, then according to Eqn. (7) the following aggregation formula is obtained

$R N G B M^{p, q}\left(R N\left(\phi_{1}\right), R N\left(\phi_{2}\right), \ldots, R N\left(\phi_{n}\right)\right)=\left(\frac{1}{n} \sum_{i \neq 1}^{n} R N\left(\phi_{i}^{p}\right)\left(\prod_{j=1}^{n} R N\left(\phi_{j}^{q}\right)\right)^{\frac{1}{n-1}}\right)^{\frac{1}{p+q}}$

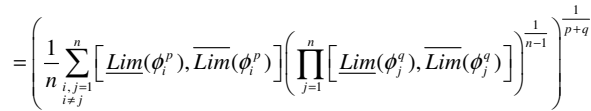

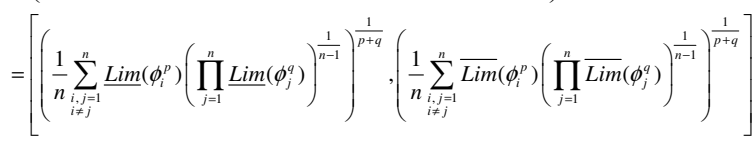

Proof.

Assume that $R N\left(\phi_{1}\right)=\left[\underline{\operatorname{Lim}}\left(\phi_{1}\right), \overline{\operatorname{Lim}}\left(\phi_{1}\right)\right]$ and are $R N\left(\phi_{2}\right)=\left[\underline{\operatorname{Lim}}\left(\phi_{2}\right), \overline{\operatorname{Lim}}\left(\phi_{2}\right)\right]$ rough numbers, then according to operations on rough numbers, Eqns. (1)-(5), the following aggregation formula is obtained

(1a) $R N\left(\phi_{i}^{p}\right)=\left[\underline{\operatorname{Lim}}\left(\phi_{i}^{p}\right), \overline{\operatorname{Lim}}\left(\phi_{i}^{p}\right)\right]$

(2a) $R N\left(\phi_{j}^{q}\right)=\left[\underline{\operatorname{Lim}}\left(\phi_{j}^{q}\right), \overline{\operatorname{Lim}}\left(\phi_{j}^{q}\right)\right]$

(3a)

$$
\begin{aligned}
& R N\left(\phi_{i}^{p}\right) \cdot R N\left(\phi_{j}^{q}\right) \\
& =\left[\underline{\operatorname{Lim}}\left(\phi_{i}^{p}\right), \overline{\operatorname{Lim}}\left(\phi_{i}^{p}\right)\right] \cdot\left[\underline{\operatorname{Lim}}\left(\phi_{j}^{q}\right), \overline{\operatorname{Lim}}\left(\phi_{j}^{q}\right)\right] \\
& =\left[\underline{\operatorname{Lim}}\left(\phi_{i}^{p}\right) \cdot \underline{\operatorname{Lim}}\left(\phi_{j}^{q}\right), \overline{\operatorname{Lim}}\left(\phi_{i}^{p}\right), \overline{\operatorname{Lim}}\left(\phi_{j}^{q}\right)\right]
\end{aligned}
$$

(4a) $\frac{1}{n} \sum_{\substack{i, j=1 \\ i \neq j}}^{n} R N\left(\phi_{i}^{p}\right)=\left[\frac{1}{n} \sum_{\substack{i, j=1 \\ i \neq j}}^{n} \underline{\operatorname{Lim}}\left(\phi_{i}^{p}\right), \frac{1}{n} \sum_{\substack{i, j=1 \\ i \neq j}}^{n} \overline{\operatorname{Lim}}\left(\phi_{j}^{q}\right)\right]$

(5a) $\left(\prod_{j=1}^{n} R N\left(\phi_{j}^{q}\right)\right)^{\frac{1}{n-1}}=\left[\left(\prod_{j=1}^{n} \underline{\operatorname{Lim}}\left(\phi_{j}^{p}\right)\right)\right]^{\frac{1}{n-1}},\left[\left(\prod_{j=1}^{n} \overline{\operatorname{Lim}}\left(\phi_{j}^{p}\right)\right)\right]^{\frac{1}{n-1}}$

(6a) $\frac{1}{n} \sum_{\substack{i, j=1 \\ i \neq j}}^{n} R N\left(\phi_{i}^{p}\right)\left(\prod_{j=1}^{n} R N\left(\phi_{j}^{q}\right)\right)^{\frac{1}{n-1}}$

$$
=\left[\begin{array}{l}
\frac{1}{n} \sum_{\substack{i, j=1 \\
i \neq j}}^{n} \underline{\operatorname{Lim}}\left(\phi_{i}^{p}\right)\left(\prod_{j=1}^{n} \underline{\operatorname{Lim}}\left(\phi_{j}^{q}\right)\right)^{\frac{1}{n-1}}, \\
\frac{1}{n} \sum_{\substack{i, j=1 \\
i \neq j}}^{n} \overline{\operatorname{Lim}}\left(\phi_{i}^{p}\right)\left(\prod_{j=1}^{n} \overline{\operatorname{Lim}}\left(\phi_{j}^{q}\right)\right)^{\frac{1}{n-1}}
\end{array}\right]
$$


(7a)

$$
\left(\frac{1}{n} \sum_{\substack{i, j=1 \\ i \neq j}}^{n} R N\left(\phi_{i}^{p}\right)\left(\prod_{j=1}^{n} R N\left(\phi_{j}^{q}\right)\right)^{\frac{1}{n-1}}\right)^{\frac{1}{p+q}}
$$$$
=\left[\begin{array}{l}
\left(\frac{1}{n} \sum_{\substack{i, j=1 \\
i \neq j}}^{n} \underline{\operatorname{Lim}}\left(\phi_{i}^{p}\right)\left(\prod_{j=1}^{n} \underline{\operatorname{Lim}}\left(\phi_{j}^{q}\right)\right)^{\frac{1}{n-1}}\right)^{\frac{1}{p+q}}, \\
\left(\frac{1}{n} \sum_{\substack{i, j=1 \\
i \neq j}}^{n} \overline{\operatorname{Lim}}\left(\phi_{i}^{p}\right)\left(\prod_{j=1}^{n} \overline{\operatorname{Lim}}\left(\phi_{j}^{q}\right)\right)^{\frac{1}{n-1}}\right)^{\frac{1}{p+q}}
\end{array}\right]
$$

If $n=r$, based on Eqns. (3a)-(7a) following equation was obtained

$$
\begin{aligned}
& \left(\frac{1}{r} \sum_{\substack{i, j=1 \\
i \neq j}}^{r} R N\left(\phi_{i}^{p}\right)\left(\prod_{j=1}^{r} R N\left(\phi_{j}^{q}\right)\right)^{\frac{1}{r-1}}\right)^{\frac{1}{p+q}} \\
& =\left[\begin{array}{l}
\left(\frac{1}{r} \sum_{i, j=1}^{r} \operatorname{Lim}\left(\phi_{i}^{p}\right)\left(\prod_{j=1}^{r} \operatorname{Lim}\left(\phi_{j}^{q}\right)\right)^{\frac{1}{r-1}}\right)^{\frac{1}{p+q}}, \\
\left(\frac{1}{r} \sum_{\substack{i, j=1 \\
i \neq j}}^{r} \operatorname{Lim}\left(\phi_{i}^{p}\right)\left(\prod_{j=1}^{r} \overline{\operatorname{Lim}}\left(\phi_{j}^{q}\right)\right)^{\frac{1}{r-1}}\right)^{\frac{1}{p+q}}
\end{array}\right]
\end{aligned}
$$

If $n=r+1$, following equation was obtained

$$
\begin{aligned}
& \left(\frac{1}{r+1} \sum_{\substack{i, j=1 \\
i \neq j}}^{r+1} R N\left(\phi_{i}^{p}\right)\left(\prod_{j=1}^{r+1} R N\left(\phi_{j}^{q}\right)\right)^{\frac{1}{(r+1)-1}}\right)^{\frac{1}{p+q}} \\
& =\left(\frac{1}{r} \sum_{\substack{i, j=1 \\
i \neq j}}^{r} R N\left(\phi_{i}^{p}\right)\left(\prod_{j=1}^{r} R N\left(\phi_{j}^{q}\right)\right)^{\frac{1}{r-1}}\right)^{\frac{1}{p+q}} \\
& +\left(\frac{1}{r+1} \sum_{\substack{i, j=1 \\
i \neq j}}^{r+1} R N\left(\phi_{i}^{p}\right)\left(\prod_{j=1}^{r+1} R N\left(\phi_{j}^{q}\right)\right)^{\frac{1}{(r+1)-1}}\right)^{\frac{1}{p+q}} \\
& {\left[\left(\frac{1}{r} \sum_{i, j=1}^{r} \underline{\operatorname{Lim}}\left(\phi_{i}^{p}\right)\left(\prod_{j=1}^{r} \underline{\operatorname{Lim}}\left(\phi_{j}^{q}\right)\right)^{\frac{1}{r-1}}\right]^{\frac{1}{p+q}}\right.} \\
& +\left(\frac{1}{r+1} \sum_{i, j=1}^{r+1} \operatorname{Lim}\left(\phi_{i}^{p}\right)\left(\prod_{j=1}^{r+1} \frac{\operatorname{Lim}}{i \neq j}\left(\phi_{j}^{q}\right)\right)^{\frac{1}{(r+1)-1}}\right)^{\frac{1}{p+q}}, \\
& \left(\frac{1}{r} \sum_{\substack{i, j=1 \\
i \neq j}}^{r} \overline{\operatorname{Lim}}\left(\phi_{i}^{p}\right)\left(\prod_{j=1}^{r} \overline{\operatorname{Lim}}\left(\phi_{j}^{q}\right)\right)^{\frac{1}{r-1}}\right)^{\frac{1}{p+q}} \\
& {\left[+\left(\frac{1}{r+1} \sum_{\substack{i, j=1 \\
i \neq j}}^{r+1} \overline{\operatorname{Lim}}\left(\phi_{i}^{p}\right)\left(\prod_{j=1}^{r+1} \overline{\operatorname{Lim}}\left(\phi_{j}^{q}\right)\right)^{\frac{1}{(r+1)-1}}\right]^{\frac{1}{p+q}}\right]}
\end{aligned}
$$

So, by using Eqs. (1)-(5) previous equation can be transformed as

$$
\begin{aligned}
& \left(\frac{1}{r+1} \sum_{\substack{i, j=1 \\
i \neq j}}^{r+1} R N\left(\phi_{i}^{p}\right)\left(\prod_{j=1}^{r+1} R N\left(\phi_{j}^{q}\right)\right)^{\frac{1}{(r+1)-1}}\right)^{\frac{1}{p+q}} \\
& =\left[\begin{array}{l}
\left(\frac{1}{r+1} \sum_{\substack{i, j=1 \\
i \neq j}}^{r+1} \underline{\operatorname{Lim}}\left(\phi_{i}^{p}\right)\left(\prod_{j=1}^{r+1} \underline{\operatorname{Lim}}\left(\phi_{j}^{q}\right)\right)^{\frac{1}{(r+1)-1}}\right)^{\frac{1}{p+q}}, \\
\left(\frac{1}{r+1} \sum_{\substack{i, j=1 \\
i \neq j}}^{r+1} \frac{\operatorname{Lim}}{\left(\phi_{i}^{p}\right.}\right)\left(\prod_{j=1}^{r+1} \overline{\operatorname{Lim}}\left(\phi_{j}^{q}\right)^{\frac{1}{(r+1)-1}}\right)^{\frac{1}{p+q}}
\end{array}\right]
\end{aligned}
$$

So, when $n=r+1$, Eqn. (8) is right then it is right for all $n$. So, Theorem 1 is true. $\mathrm{w}$

Theorem 2. (Idempotency). Set $R N\left(\phi_{i}\right)=\left[\operatorname{Lim}\left(\phi_{i}\right), \overline{\operatorname{Lim}}\left(\phi_{i}\right)\right](i=1,2, \ldots, n) \quad$ as $\quad$ a collection of RNs in $\Theta$, if $R N\left(\phi_{1}\right)=R N(\phi)$, then $\operatorname{RNGBM}^{p, q}\left(R N\left(\phi_{1}\right), \quad R N\left(\phi_{2}\right), \ldots\right.$, $\left.R N\left(\phi_{n}\right)\right)=\mathrm{RNWBM}^{p}, q(R N(\phi), R N(\phi), \ldots$, $R N(\phi))$.

Proof.

Since $R N\left(\phi_{1}\right)=R N(\phi)$, i.e. $\underline{\operatorname{Lim}}\left(\phi_{i}\right)=\underline{\operatorname{Lim}}(\phi)$, $\overline{\operatorname{Lim}}\left(\phi_{i}\right)=\overline{\operatorname{Lim}}(\phi)$ for $i=1,2, \ldots, n$, then $R N G B M^{p, q}\left(R N\left(\phi_{1}\right), R N\left(\phi_{2}\right), \ldots, R N\left(\phi_{n}\right)\right)=R N G B M^{p, q}(R N(\phi), R N(\phi), . ., R N(\phi))$

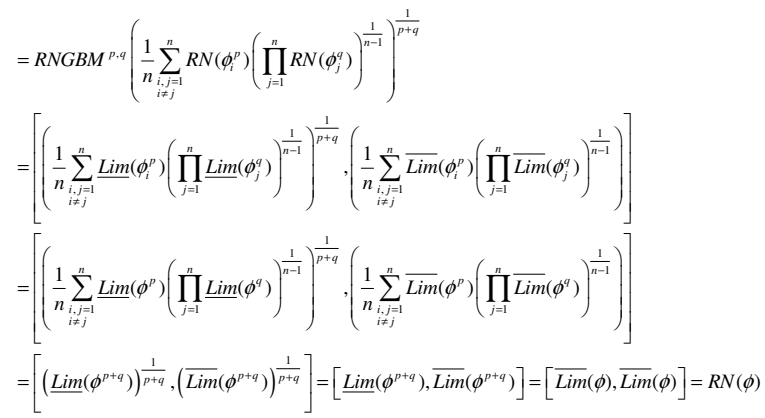

The proof of Theorem 2 is completed. $\mathrm{w}$

Theorem 3. (Boundedness).

Let $\quad R N\left(\phi_{i}\right)=\left[\underline{\operatorname{Lim}}\left(\phi_{i}\right), \overline{\operatorname{Lim}}\left(\phi_{i}\right)\right] \quad(i=1,2, \ldots, n)$ as a collection of IGNs in $\Theta$, let $R N\left(\phi^{-}\right)=\left[\min \underline{\operatorname{Lim}}\left(\phi_{i}\right), \min \overline{\operatorname{Lim}}\left(\phi_{i}\right)\right] \quad$ and 
$R N\left(\phi^{+}\right)=\left[\max \underline{\operatorname{Lim}}\left(\phi_{i}\right), \max \overline{\operatorname{Lim}}\left(\phi_{i}\right)\right]$, then $R N\left(\phi^{-}\right)$ $\leq R N G B M^{p}, q\left(R N\left(\phi_{1}\right), R N\left(\phi_{2}\right), \ldots, R N\left(\phi_{n}\right)\right) \leq$ $R N\left(\phi^{+}\right)$.

Proof.

Let $R N\left(\phi^{-}\right)=\min \left(R N\left(\phi_{1}\right), R N\left(\phi_{2}\right), \ldots\right.$, $\left.R N\left(\phi_{n}\right)\right)=\left\lfloor\min \underline{\operatorname{Lim}}\left(\phi_{i}\right), \min \overline{\operatorname{Lim}}\left(\phi_{i}\right)\right\rfloor \quad$ and $R N\left(\phi^{+}\right)=\max \left(R N\left(\phi_{1}\right), R N\left(\phi_{2}\right), \ldots, R N\left(\phi_{n}\right)\right)=$ $\left[\max \underline{\operatorname{Lim}}\left(\phi_{i}\right), \max \overline{\operatorname{Lim}}\left(\phi_{i}\right)\right]$. Then, it is $\underline{\operatorname{Lim}}\left(\phi^{-}\right)=\min _{i}\left(\underline{\operatorname{Lim}}\left(\phi_{i}\right)\right), \overline{\operatorname{Lim}}\left(\phi^{-}\right)=\min \left(\overline{\operatorname{Lim}}\left(\phi_{i}\right)\right)$, $\underline{\operatorname{Lim}}\left(\phi^{+}\right)=\max _{i}\left(\underline{\operatorname{Lim}}\left(\phi_{i}\right)\right)$ and $\operatorname{Lim}\left(\phi^{+}\right)=\max _{i}\left(\operatorname{Lim}\left(\phi_{i}\right)\right)$

Based on that, it is

$$
\begin{aligned}
& R N\left(\phi^{-}\right) \leq R N\left(\phi_{i}\right) \leq R N\left(\phi^{+}\right) ; \\
& \min _{i}\left(\underline{\operatorname{Lim}}\left(\phi_{i}\right) \leq \underline{\operatorname{Lim}}\left(\phi_{i}\right) \leq \max _{i}\left(\underline{\operatorname{Lim}}\left(\phi_{i}\right)\right) ;\right. \\
& \min _{i}\left(\overline{\operatorname{Lim}}\left(\phi_{i}\right)\right) \leq \overline{\operatorname{Lim}}\left(\phi_{i}\right) \leq \max _{i}\left(\overline{\operatorname{Lim}}\left(\phi_{i}\right)\right) .
\end{aligned}
$$

According to inequalities showed above, $R N\left(\phi^{-}\right) \leq R N G B M^{p, q}\left(R N\left(\phi_{1}\right), R N\left(\phi_{2}\right), \ldots\right.$, $\left.R N\left(\phi_{n}\right)\right) \leq R N\left(\phi^{+}\right)$holds. w

Theorem 4. (Commutativity).

Let rough set $\left(R N\left(\phi_{1}^{\prime}\right), R N\left(\phi_{2}^{\prime}\right), \ldots\right.$, $\left.R N\left(\phi_{n}^{\prime}\right)\right)$ be any permutation of $\left(R N\left(\phi_{1}\right)\right.$, $\left.R N\left(\phi_{2}\right), \ldots, \quad R N\left(\phi_{n}\right)\right)$. Then there is $R N G B M^{p, q}\left(R N\left(\phi_{1}\right), R N\left(\phi_{2}\right), \ldots, \quad R N\left(\phi_{n}\right)\right)=$ $R N G B M^{p, q}\left(R N\left(\phi_{1}^{\prime}\right), R N\left(\phi_{2}^{\prime}\right), \ldots, R N\left(\phi_{n}^{\prime}\right)\right)$.

Proof. The property is obvious. $\mathrm{w}$

\subsection{Best-Worst Method}

In this study, the authors have chosen to apply BWM for determining the weight coefficients of the criteria due to following advantages (Rezaei, 2015): (1) A smaller number of comparisons in pairs, e.g. The Analytical Hierarchy Process (AHP) method requires $n$ (n-1) / 2 comparisons, while BWM requires $2 \mathrm{n}$-3comparisons; (2) Weight coefficients obtained using BWM are more reliable - comparisons are made with a higher degree of consistency; (3) In most models for multi-criteria decision-making (MCDM), e.g. AHP method, the degree of consistency represents a verification whether the comparisons of criteria are consistent or not; in BWM the degree of consistency is used to determine the level of reliability since BWM outputs are always consistent; (4) When comparing in criterion pairs BWM uses only integer values unlike AHP which also requires the use of fractional values (Nunić, 2018). Next section shows BWM algorithm that includes the following steps:

Step 1. Identification of the evaluation criteria set $C=\left\{c_{1}, c_{2}, \ldots, c_{n}\right\}$, where $\mathrm{n}$ is the total number of criteria.

Step 2. Identification of a single criterion with the most dominant and the most inferior impact provided that if there are two or more criteria of the same importance only one is arbitrarily chosen.

Step 3. Determining dominance of the most important criterion from set in relation to other criteria of the same set, this is measured on a scale of numbers 1-9. The measurement result is presented by vector „best in relation to others" (BO):

$A_{B}=\left(a_{B 1}, a_{B 2}, \ldots, a_{B n}\right)$

where $a_{B j}$ presents the advantage of the most dominant criterion $\mathrm{B}$ in relation to criterion $j$, where $a_{B B}=1$.

Step 4. Determining dominance of all the criteria from set $C$ in relation to the most inferior criterion of the set, expressed by a number on scale 1-9. The result of measurement is presented by vector ,others 
compared to the worst" (OW):

$A_{W}=\left(a_{1 W}, a_{2 W}, \ldots, a_{n W}\right)$

where $a_{j W}$ presents the dominance of criterion $j$ in relation to the worst criterion $W$, where $a_{W W}=1$.

Step 5. Calculation of optimal values of weight coefficients of the criteria from set $C$, $\left(w_{1}{ }^{*}, w_{2}{ }^{*}, \ldots, w_{n}{ }^{*}\right)$ whereby the condition should be satisfied that maximum absolute values of differences (11)

$\left|\frac{w_{B}}{w_{j}}-a_{B j}\right|$ and $\left|\frac{w_{j}}{w_{w}}-a_{j W}\right|$

for all values of $j$ are minimized. This condition can be presented by the following minimax model:

$\min \max _{j}\left\{\left|\frac{w_{B}}{w_{j}}-a_{B j}\right|,\left|\frac{w_{j}}{w_{w}}-a_{j W}\right|\right\}$

s.t.

$\sum_{j=1}^{n} w_{j}=1$

$w_{j} \geq 0 \quad \forall j$

The previous model (12) can be shown by an equivalent model in the following way:

$\min \xi$

s.t.

$\left|\frac{w_{B}}{w_{j}}-a_{B j}\right| \leq \xi, \forall j$

$\left|\frac{w_{j}}{w_{w}}-a_{j W}\right| \leq \xi, \forall j$

$\sum_{j=1}^{n} w_{j}=1$

$w_{j} \geq 0 \quad \forall j$
By solving the system of equations and inequalities of the model (13), the optimal values of weight coefficients of the evaluation are obtained $\left(w_{1}{ }^{*}, w_{2}{ }^{*}, \ldots, w_{n}{ }^{*}\right)$ and $\xi^{*}$.

For each value $a_{B W} \in\{1,2, \ldots, 9\}$ the values of consistency index are calculated $C I(\max \xi) \in\{0.00,0.44, \ldots, 5.23, \quad$ (Rezaei, 2015).

It is considered that the values of weight coefficients of the evaluation are reliable if the condition presented by the expression (14) is satisfied, (Rezaei, 2015).

$C R=\frac{\xi^{*}}{C I} \leq 0,25$

$C R \in[0,1]$

where $C R$ is the degree of consistency.

From the expression (14) it can be noticed that as the value $\xi^{*}$ increases, the value of increases, that is, the reliability of comparison results of criteria defined by experts is decreased.

If the condition presented by the expression (14) is not satisfied, the optimal weight coefficients of criteria are calculated in the form of interval numbers by solving the model (15)

$$
\begin{array}{ll}
\min w_{j} & \max w_{j} \\
\text { s.t. } & \text { s.t. } \\
\left|\frac{w_{B}}{w_{j}}-a_{B j}\right| \leq \xi^{*}, \forall j & \left|\frac{w_{B}}{w_{j}}-a_{B j}\right| \leq \xi^{*}, \forall j \\
\left|\frac{w_{j}}{w_{w}}-a_{j W}\right| \leq \xi^{*}, \forall j & \left|\frac{w_{j}}{w_{w}}-a_{j W}\right| \leq \xi^{*}, \forall j \\
\sum_{j=1}^{n} w_{j}=1 & \sum_{j=1}^{n} w_{j}=1 \\
w_{j} \geq 0 \forall j & w_{j} \geq 0 \forall j
\end{array}
$$


For each interval value, the center of interval is determined, which is used to rank the criteria of alternatives, (Rezaei, 2016).

\subsection{Rough MAIRCA method}

Rough numbers (RN) (Zhai et al., 2008) represent objectively expressed interval values (lower, upper approximation boundary, and a boundary interval of the object) obtained by processing subjective assessments of respondents (experts) about a particular phenomenon during the research. The use of rough numbers improves the objectivity of decision-making process. The essence of R'MAIRCA method is to calculate the deviation of empirical interval values from the ideal estimates of criteria.The deviation sum of the defined criteria represents total deviation for each observed alternative. Ranking of alternatives is done according to value of calculated deviations, and for the best alternative the one with the lowest deviation value from the ideal values of criteria is chosen (Pamučar et al., 2014). R'MAIRCA method is carried out in 6 steps (Gigović et al., 2016; Pamucar et al., 2017; Chatterjee et al., 2018):

Step 1. Forming the initial decision making matrix $(X)$, expression (16), in which based on the expression for representation of rough numbers $(R N)$ vectors are defined $A_{i}=\left(R N\left(x_{i 1}\right), R N\left(x_{i 2}\right), \ldots, R N\left(x_{i n}\right)\right)$ where $R N\left(x_{i j}\right)=\left[\underline{\operatorname{Lim}}\left(x_{i j}\right), \overline{\operatorname{Lim}}\left(x_{i j}\right)\right]$ presents the value of $i$ alternative according to $j$ criterion $(i=1,2, \ldots, m ; j=1,2, \ldots, n)$.

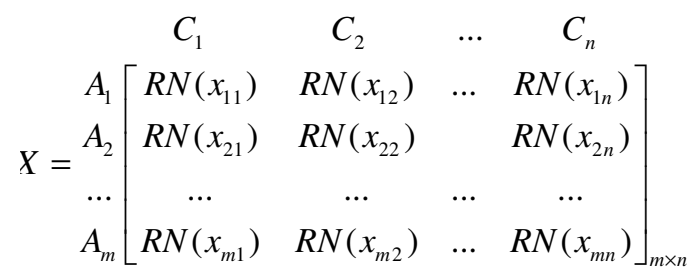

Matrix elements (16) are made of rough numbers obtained by arithmetic operations used for interval numbers (Liu \& Lv, 2014), based on the preferences of the decision maker or the aggregation of expert assessments.

Step 2. Determining the preference according to the choice of alternatives $P_{A_{i}}$, when the decision maker (DM) is neutral, or views alternatives from the aspect of equal probability of choice, from which it follows that the preference for choosing one of $m$ possible alternatives is

$$
P_{A_{i}}=\frac{1}{m} ; \sum_{i=1}^{m} P_{A_{i}}=1, i=1,2, \ldots, m
$$

Step 3. Calculation of the elements of theoretical assessment matrix $\left(T_{p}\right), n \times m$ format, where $n$ is the total number of criteria, and $m$ is the total number of alternatives. The elements of theoretical assessment matrix $\left(t_{p i j}\right)$ are rough numbers and are calculated as a product of preferences to the choice of alternatives $P_{A_{i}}$ and weight coefficients of the criteria $\left(w_{i}\right.$, $i=1,2, \ldots, n)$ which are obtained using BWM

$$
\begin{aligned}
& R N\left(w_{1}\right) \quad R N\left(w_{2}\right) \quad \ldots \quad R N\left(w_{n}\right) \\
& T_{p}=\begin{array}{c}
P_{A_{1}} \\
P_{A_{2}} \\
\ldots \\
P_{A_{m}}
\end{array}\left[\begin{array}{cccc}
R N\left(t_{p 11}\right) & R N\left(t_{p 12}\right) & \ldots & R N\left(t_{p 1 n}\right) \\
R N\left(t_{p 21}\right) & R N\left(t_{p 22}\right) & & R N\left(t_{p 2 n}\right) \\
\ldots & \ldots & \ldots & \ldots \\
R N\left(t_{p m 1}\right) & R N\left(t_{p m 2}\right) & \ldots & R N\left(t_{p m n}\right)
\end{array}\right]_{m \times n}
\end{aligned}
$$

where $P_{A_{i}}$ presents preferences to the choice of alternatives, $R N\left(w_{i}\right)$ weight coefficients of the evaluation criteria, and $R N\left(t_{p i j}\right)$ theoretical assessment of the alternative for the observed evaluation criterion. The matrix elements $T_{p}$ are calculated using the expression (19)

$R N\left(t_{p i j}\right)=P_{A i} \cdot R N\left(w_{i}\right)=P_{A i} \cdot\left[\underline{\operatorname{Lim}}\left(w_{i}\right), \overline{\operatorname{Lim}}\left(w_{i}\right)\right]$ 
Taking into account that the preferences of a decision maker $P_{A_{i}}$ are the same for all alternatives, the matrix (18) can be transposed into a format $n \times 1$,

$$
\begin{gathered}
T_{p}=P_{A_{i}} \quad\left[P_{A_{i}} \cdot\left[\underline{\operatorname{Lim}}\left(w_{1}\right), \overline{\operatorname{Lim}}\left(w_{1}\right)\right]\right. \\
R N\left(w_{2}\right) \\
P_{A_{i}} \cdot\left[\underline{\operatorname{Lim}}\left(w_{2}\right), \overline{\operatorname{Lim}}\left(w_{1}\right)\right] \ldots \\
R N\left(w_{n}\right) \\
\left.P_{A_{i}} \cdot\left[\underline{\operatorname{Lim}}\left(w_{n}\right), \overline{\operatorname{Lim}}\left(w_{n}\right)\right]\right]_{n x 1}
\end{gathered}
$$

where $n$ is the total number of evaluation criteria.

Step 4: Calculation of the elements of real assessment matrix $(T)$ by multiplying the elements of theoretical assessment matrix $\left(T_{p}\right)$ and the elements of initial decision making matrix $(X)$ according to the expression:

$$
\begin{aligned}
& R N\left(t_{r i j}\right)=R N\left(t_{p i j}\right) \cdot R N\left(x_{n i j}\right) \\
& =\left[\underline{\operatorname{Lim}}\left(x_{p i j}\right) \cdot \underline{\operatorname{Lim}}\left(x_{n i j}\right), \overline{\operatorname{Lim}}\left(t_{p i j}\right) \cdot \overline{\operatorname{Lim}}\left(x_{n i j}\right)\right]
\end{aligned}
$$

where $R N\left(t_{p i j}\right) \quad$ represents the elements of theoretical assessment matrix, and $R N\left(x_{n i j}\right)$ presents normalized elements of the initial decision making matrix (16). Normalization of elements of the initial decision making matrix (16) is done using the expression (22)

$$
\begin{aligned}
& R N\left(x_{n i j}\right)=\left[\underline{\operatorname{Lim}}\left(x_{n i j}\right) \overline{\operatorname{Lim}}\left(x_{n i j}\right)\right]=\left[x_{n i j}^{L}, x_{n i j}^{U}\right] \\
& = \begin{cases}{\left[\frac{x_{n i j}^{L}-x_{j}^{-}}{x_{j}^{+}-x_{j}^{-}}, \frac{x_{n i j}^{U}-x_{j}^{-}}{x_{j}^{+}-x_{j}^{-}}\right] ; \text {if } j \in B,} \\
{\left[\frac{x_{n i j}^{U}-x_{j}^{+}}{x_{j}^{-}-x_{j}^{+}}, \frac{x_{n i j}^{L}-x_{j}^{+}}{x_{j}^{-}-x_{j}^{+}}\right] ; \text {if } j \in C .}\end{cases}
\end{aligned}
$$

where $x_{j}^{-}=\min _{j}\left\{\underline{\operatorname{Lim}}\left(x_{n i j}\right)\right\}=\min _{j}\left\{x_{n i j}^{L}\right\} \quad$ and $x_{j}^{+}=\max _{j}\left\{\overline{\operatorname{Lim}}\left(x_{n i j}\right)\right\}=\max _{j}\left\{x_{n i j}^{U}\right\} \quad$ respectively are minimum and maximum values of boundary intervals of the observed criterion, while $B$ and $C$ represent a set of ,benefit" and ,cost” criteria, respectively.

Step 5. Calculating the total gap matrix $(G)$. The matrix elements $G$ represent the deviation of theoretical $\left(t_{p i j}\right)$ from real assessments $\left(t_{r i j}\right)$ and are obtained by subtracting the elements of theoretical weights matrix $\left(T_{p}\right)$ from the elements of real weights matrix $\left(T_{r}\right)$

$$
G=T_{p}-T_{r}=\left[\begin{array}{cccc}
g_{11} & g_{12} & \ldots & g_{1 n} \\
g_{21} & g_{22} & \ldots & g_{2 n} \\
\ldots & \ldots & \ldots & \ldots \\
g_{m 1} & g_{m 2} & \cdots & g_{m n}
\end{array}\right]_{m \times n}
$$

where $n$ is the total number of criteria, $m$ is the total number of alternatives that are chosen, and $g_{i j}$ represents the deviation (gap) of the alternative $i$ according to criterion $j$. The deviation $g_{i j}$ in the concrete model is a real number obtained by calculating the Euclidean distance of boundary values of rough numbers using the expression (24)

$$
\begin{aligned}
& g_{i j}=\sqrt{\left(\operatorname{Lim}\left(t_{p i j}\right)-\underline{\operatorname{Lim}}\left(t_{r i j}\right)\right)^{2}+\left(\overline{\operatorname{Lim}}\left(t_{p i j}\right)-\operatorname{Lim}\left(t_{r i j}\right)\right)^{2}}, \\
& j=1,2, \ldots, n, \quad i=1,2, \ldots, m
\end{aligned}
$$

The best (ideal) alternative $A_{i}$ according to criterion $C_{i}$ is the one in which the deviation $g_{i j}$ gravitates to zero $\left(g_{i j} \rightarrow 0\right)$, that is the one with the least difference between theoretical $\left(t_{p i j}\right)$ and actual assessments $\left(t_{r i j}\right)$. If the alternative $A_{i}$ for criterion $C_{i}$ has the value of theoretical weights that is equal to the value of real weights $\left(t_{p i j}=t_{r i j}\right)$, then the gap for alternative $A_{i}$ according to criterion $C_{i}$ gravitates to zero. 
If the alternative $A_{i}$ for criterion $C_{i}$ has the dominance threshold $I_{D}$ is determined

value of theoretical weights that is $t_{p i j}$ and the value of real weights that gravitates to zero, then the gap for alternative $A_{i}$ according to criterion $C_{i}$ is $g_{i j} \approx t_{p i j}$. This means that the alternative $A_{i}$ according to criterion $C_{i}$ is the worst (anti-ideal) alternative.

Step 6. Calculating the final values of criterion functions $\left(Q_{i}\right)$ according to alternatives.

The values of criterion functions are obtained by summing the gap from the matrix (23) for each alternative according to the evaluation criteria, i.e. summing the matrix elements $(G)$ by columns, expression (25)

$Q_{i}=\sum_{j=1}^{n} g_{i j}, j=1,2, \ldots, n ; i=1,2, \ldots, m$

Ranking of alternatives in a particular model will be done based on the results obtained in the form of real numbers.

Step 7. Determining dominance index of the first-ranked alternative $\left(A_{D, 1-j}\right)$. The dominance index of the first-ranked alternative defines its advantage over the other alternatives. The dominance index is determined using the expression (26)

$A_{D, 1-j}=\frac{Q_{j}-Q_{1}}{Q_{n}}, j=2,3, . ., m$

where $Q_{1}$ is the criterion function of the firstranked alternative, $Q_{n}$ is the criterion function of the alternative that is last in ranking, $Q_{j}$ is the criterion function of the alternative with which the first ranked alternative is compared, $m$ is the total number of alternatives. After determining the dominance index, using the expression (27)

$$
I_{D}=\frac{m-1}{m^{2}}
$$

If the condition is satisfied that the dominance index $A_{D, 1-j}$ is greater than or equal to the dominance threshold $I_{D}\left(A_{D, 1-j}\right.$ $\geq I_{D}$ ), the obtained rank is retained. If the dominance index $A_{D, 1-j}$ is less than the dominance threshold $I_{D}\left(A_{D, 1-j}<I_{D}\right)$, the first-ranked alternative does not have a sufficient advantage over the observed alternative. The specified restrictions can be shown by the following relation (28)

$$
R_{\text {final }, j}=\left\{\begin{array}{lll}
A_{D, 1-j} \geq I_{D} & \Rightarrow & R_{\text {final }, j}=R_{\text {initial }, j} \\
A_{D, 1-j}<I_{D} & \Rightarrow & R_{\text {final }, j}=R_{\text {initial }, 1}
\end{array}\right.
$$

where $R_{\text {initial, } j}$ is the initial rank of the alternative with which the first-ranked alternative is compared, $R_{f i n a l, j}$ is the final rank of the alternative with which the firstranked alternative is compared, and $A_{D, 1-j}$ the dominance index of the first-ranked alternative in relation to considered alternative.

\section{THE EVALUATION OF MENU USING BWM-R'MAIRCA MODEL}

As previously mentioned, hybrid BWMR'MAIRCA model is realized through two stages. The first stage of the model implies the application of BWM for calculation of interval weight coefficients of the criteria. In the second stage, the evaluation of menu is carried out using R'MAIRCA model. The evaluation of menu, in addition to ranking, also means comparing the obtained ranks 
with the ranks suggested from other models of multi-criteria decision-making, in this case MABAC and VIKOR. The selection of the optimal menu was performed after obtaining the results, using different methods, then calculating Spearman's rank correlation coefficient and performing sensitivity analysis of BWM-R'MAIRCA model. A more detailed implementation

Table 1. Evaluation Criteria process of certain phases of BWMR'MAIRCA model is shown in the next section.

\subsection{Determining the weights of criteria using BWM}

In the first step, based on the expert experience, nine relevant criteria for menu

\begin{tabular}{|c|c|c|}
\hline $\begin{array}{l}\text { Criterion } \\
\text { label }\end{array}$ & Criterion name & Explanation \\
\hline$C 1$ & Time needed for preparation & The duration of technological process \\
\hline$C 2$ & TTOR storage of meal components & Space, appliances and storage facilities \\
\hline$C 3$ & TTOR for meal preparation & $\begin{array}{l}\text { Space, machines, appliances, accessories, recipes, } \\
\text { qualifications of people }\end{array}$ \\
\hline$C 4$ & Price & Cost of fresh foods \\
\hline C5 & Energy value & Caloric value of a meal \\
\hline C6 & Digestibility & $\begin{array}{l}\text { A subjective feeling in the body after consuming } \\
\text { a meal }\end{array}$ \\
\hline$C 7$ & Sensory properties & Appearance, smell, taste, texture \\
\hline$C 8$ & Elan for work & Mental and physical work after the meal \\
\hline$C 9$ & $\begin{array}{l}\text { The possibility of preparation in unforeseen } \\
\text { circumstances }\end{array}$ & In case of TTOR dysfunction \\
\hline
\end{tabular}

Table 2. BO vector of compared criteria

\begin{tabular}{ccccccccccccc}
\hline & Criterion & E1 & E2 & E3 & E4 & E5 & E6 & E7 & E8 & E9 & Geo. mean. & Rank \\
\cline { 2 - 11 } & C1 & 4 & 6 & 7 & 4 & 8 & 9 & 4 & 5 & 5 & 5,53 & 8 \\
BO & C2 & 2 & 2 & 8 & 8 & 7 & 8 & 1 & 9 & 9 & 4,72 & 6 \\
& C3 & 1 & 1 & 5 & 7 & 2 & 2 & 2 & 6 & 8 & 2,88 & 2 \\
& C4 & 3 & 7 & 3 & 9 & 3 & 6 & 3 & 8 & 7 & 4,93 & 7 \\
& C5 & 7 & 3 & 1 & 2 & 1 & 5 & 7 & 1 & 1 & 2,25 & $1(\mathrm{~B})$ \\
& C6 & 8 & 4 & 4 & 6 & 4 & 3 & 9 & 2 & 3 & 4,30 & 4 \\
& C7 & 5 & 5 & 2 & 3 & 9 & 7 & 6 & 3 & 6 & 4,65 & 5 \\
& C8 & 9 & 8 & 9 & 1 & 5 & 1 & 8 & 4 & 2 & 3,90 & 3 \\
& C9 & 6 & 9 & 6 & 5 & 6 & 4 & 5 & 7 & 4 & 5,60 & $9(\mathrm{~W})$ \\
\hline
\end{tabular}

Table 3. OW vector of compared criteria

\begin{tabular}{cccccccccccccc}
\hline \multirow{5}{*}{} & Criterion & E1 & E2 & E3 & E4 & E5 & E6 & E7 & E8 & E9 & Geo. mean & Rank \\
\cline { 2 - 11 } OW & C1 & 6 & 4 & 3 & 6 & 2 & 1 & 6 & 5 & 5 & 3,70 & 2 \\
& C2 & 8 & 8 & 2 & 2 & 3 & 2 & 9 & 1 & 1 & 2,88 & 4 \\
& C3 & 9 & 9 & 5 & 3 & 8 & 8 & 8 & 4 & 2 & 5,55 & 8 \\
& C4 & 7 & 3 & 7 & 1 & 7 & 4 & 7 & 2 & 3 & 3,82 & 3 \\
& C5 & 3 & 7 & 9 & 8 & 9 & 5 & 3 & 9 & 9 & 6,34 & $9(\mathrm{~B})$ \\
& C6 & 2 & 6 & 6 & 4 & 6 & 7 & 1 & 8 & 7 & 4,44 & 6 \\
& C7 & 5 & 5 & 8 & 7 & 1 & 3 & 4 & 7 & 4 & 4,27 & 5 \\
C8 & 1 & 2 & 1 & 9 & 5 & 9 & 2 & 6 & 8 & 3,49 & 7 \\
& C9 & 4 & 1 & 4 & 5 & 4 & 6 & 5 & 3 & 6 & 3,82 & $1(\mathrm{~W})$ \\
\hline
\end{tabular}


evaluation have been identified: Time required for preparation, Technicaltechnological and organizational requirements (TTOR) for storage of meal components, TTOR for meal preparation, Price, Energy value, Digestibility, Sensory properties, Elan for work and Possibility of preparation in unforeseen circumstances, for which the labels and explanations are given in Table 1 (Arsic et al., 2018).

In the second step, BWM (Rezaei, 2015) was applied and a comparison of the best criterion with the others was made using nine-degree scale [1.9], where 1 is the same significance, and 9 is a distinct dominance. The survey included nine reference experts with a minimum of ten years experience who carried out a comparison and the obtained results were presented with nine $\mathrm{BO}$ vectors (Table 2).

In the next step, the experts compared the worst criteria with the others and the results were presented with nine OW vectors, (Table $3)$.

The values of $\mathrm{BO}$ and $\mathrm{OW}$ vectors were aggregated using the expression for geometric mean (GM) calculation, and then they were assigned with ranks which were used to form the model (13). Thus, for OW vector in Table 3 for criterion $\mathrm{C} 1$, averaging was carried out as follows

$G M_{1}=\sqrt[9]{E_{1} \cdot E_{2} \cdot, \ldots, \cdot E_{9}}=\sqrt[9]{6 \cdot 4 \cdot 3 \cdot 6 \cdot 2 \cdot 1 \cdot 6 \cdot 5 \cdot 5}=3.70$

In the same way, the ranks of remaining criteria in Table 2 and Table 3 were obtained. Based on the acquired values of criteria ranks, the model was set (13)

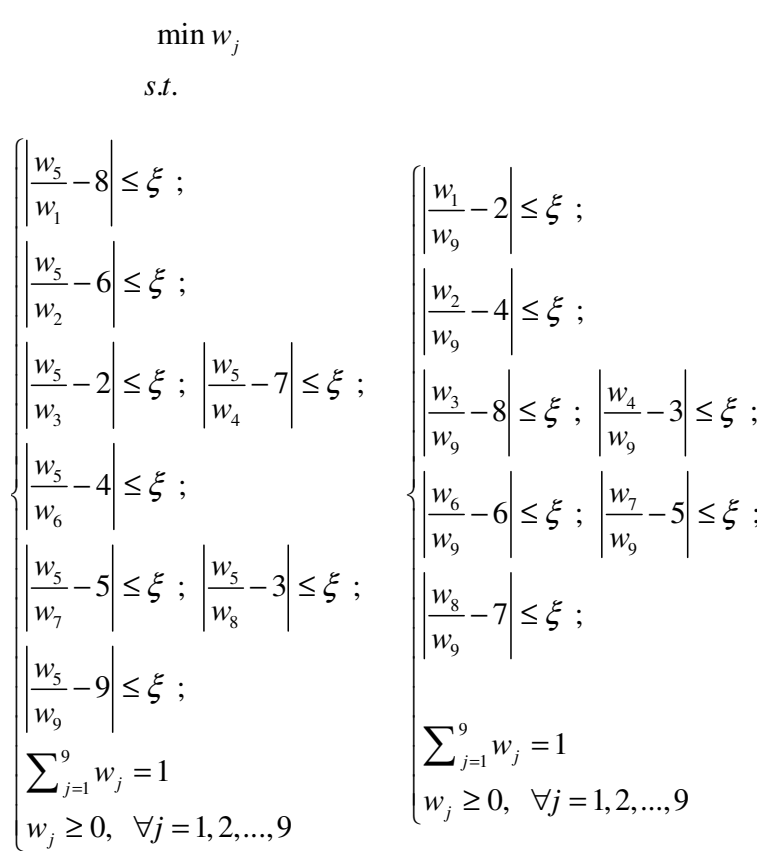

Presented model is solved using Lingo 17.0 software. By solving this model, the final values of weight coefficients were obtained

$$
\begin{aligned}
& w_{1}=0.03687 ; \\
& w_{2}=0.06155 ; \\
& w_{3}=0.19627 ; \\
& w_{4}=0.04988 ; \\
& w_{5}=0.26313 ; \\
& w_{6}=0.11567 ; \\
& w_{7}=0.08035 ; \\
& w_{8}=0.17174 ; \\
& w_{9}=0.02453 .
\end{aligned}
$$

Using the expression (14), the value of consistency degree $(C R)$ is calculated,

$C R=\frac{\xi^{*}}{C I}=\frac{1,725083}{5,23}=0.3298$

Since the minimum consistency condition is not satisfied $(C R>0.25)$, the optimal weight coefficients of criteria are calculated in the form of interval values by solving the model (15). In the following section a model for obtaining the interval values of weight coefficient of the first criterion is shown. 


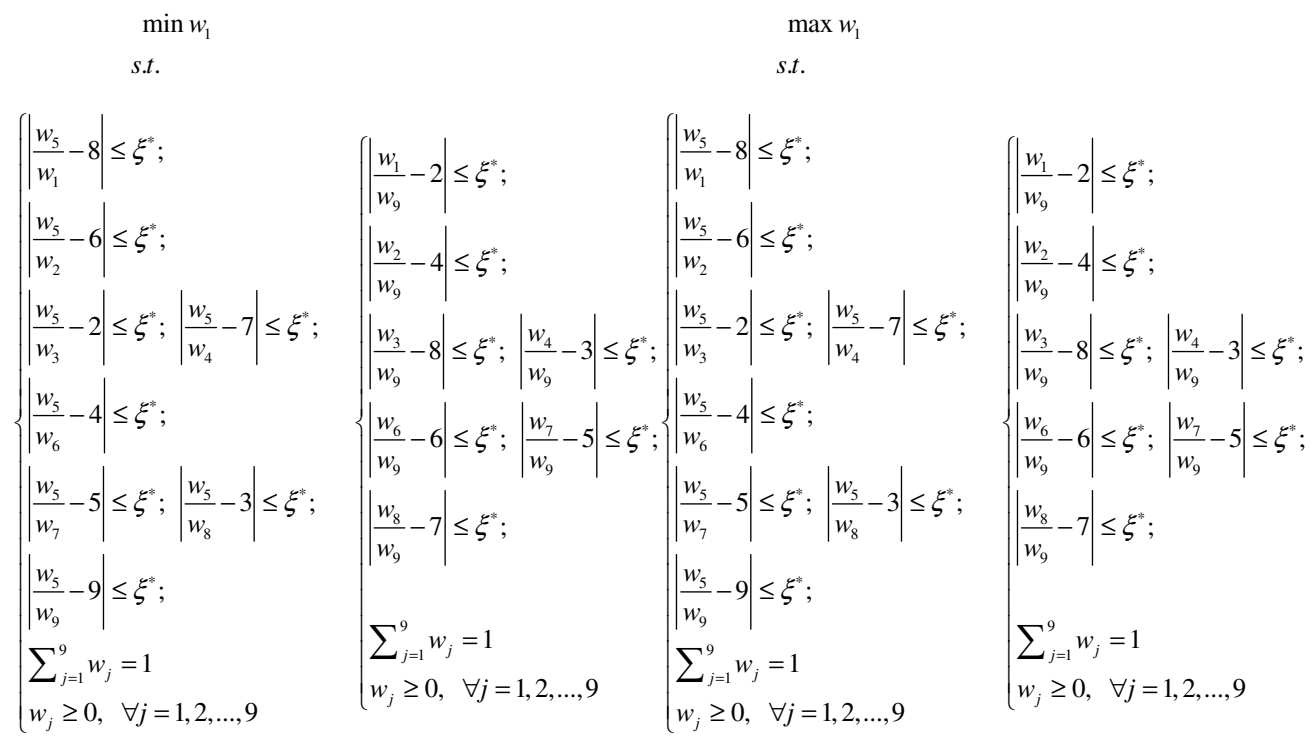

In the same way, non-linear mathematical models for the remaining criteria (C2-C9) are constructed, with limitations. By solving these limitations, the interval values of weight coefficients of the remaining criteria are obtained. The obtained intervals, lower boundary (LB) and upper boundary (UB), are shown in Table 4.

Since the evaluation of menu dishes Table 4. Boundary values of weight coefficient intervals

\begin{tabular}{ccc}
\hline$w_{j}$ & $L B$ & $U B$ \\
\hline$w_{1}$ & 0.02535418 & 0.04736751 \\
$w_{2}$ & 0.05185670 & 0.07025333 \\
$w_{3}$ & 0.15435290 & 0.24982500 \\
$w_{4}$ & 0.02941330 & 0.05611102 \\
$w_{5}$ & 0.24318140 & 0.30230740 \\
$w_{6}$ & 0.09790565 & 0.13126080 \\
$w_{7}$ & 0.07425574 & 0.09230993 \\
$w_{8}$ & 0.12876410 & 0.21785330 \\
$w_{9}$ & 0.02267408 & 0.02818695 \\
\hline
\end{tabular}

Table 5.Initial decision making matrix

\begin{tabular}{|c|c|c|c|c|c|c|c|c|c|}
\hline Alter./Crite. & $C 1$ & $C 2$ & $C 3$ & C4 & C5 & C6 & $C 7$ & C8 & $C 9$ \\
\hline$A 1$ & {$[2.707,3.238]$} & {$[3.173,3.846]$} & {$[2.542,3.117]$} & 225 & 1121 & {$[2.568,3.939]$} & {$[2.466,3.892]$} & {$[2.53,3.998]$} & {$[3.157,3.633]$} \\
\hline$A 2$ & {$[2.871,3.39]$} & {$[2.884,3.975]$} & {$[2.521,3.571]$} & 136 & 1190 & {$[2.247,4.099]$} & {$[2.584,4.069]$} & {$[2.837,4.302]$} & {$[3.157,3.633]$} \\
\hline$A 3$ & {$[3.784,4.464]$} & {$[2.888,3.879]$} & {$[2.603,4.313]$} & 108 & 1004 & {$[2.61,4]$} & {$[2.405,3.913]$} & {$[2.671,4.034]$} & {$[3.709,4.78]$} \\
\hline A4 & {$[3.102,4.206]$} & {$[2.8,3.718]$} & {$[2.776,3.707]$} & 106 & 1132 & {$[1.904,3.541]$} & {$[1.502,3.299]$} & {$[2.165,3.384]$} & {$[3.389,4.659]$} \\
\hline A5 & {$[1.151,1.626]$} & {$[2.159,3.195]$} & {$[1.421,2.278]$} & 70 & 1088 & {$[2.794,4.31]$} & {$[1.962,3.738]$} & {$[2.505,3.908]$} & {$[1.207,2.102]$} \\
\hline A6 & {$[1.207,1.706]$} & {$[1.626,2.337]$} & {$[1.33,1.978]$} & 205 & 863 & {$[1.99,4.044]$} & {$[2.019,3.978]$} & {$[2.495,4.155]$} & {$[1.424,1.886]$} \\
\hline A7 & {$[1.151,1.626]$} & {$[1.415,2.157]$} & {$[1.104,1.536]$} & 83 & 966 & {$[4.017,4.798]$} & {$[3.657,4.648]$} & {$[3.741,4.681]$} & {$[1.338,2.247]$} \\
\hline
\end{tabular}

\footnotetext{
${ }^{1}$ A pepper-based condiment made principally from red peppers. It
} may also contain garlic, eggplant and chili peppers. (alternatives) will be done using R'MAIRCA model, the obtained interval values of weight coefficients in the next section will be considered as interval i.e. rough numbers.

\subsection{The evaluation of menu using R'MAIRCA model}

Alternatives (menu dishes) that are evaluated in R'MAIRCA model are; "Tea, bacon, feta cheese, boiled egg" (A1), "Coffee milk, hot dogs, boiled egg, melted cheese" (A2), "Yogurt, French toast, cream cheese, ketchup" (A3), "Tea, potato pie, sour cream"(A4), "Tea, margarine, honey" (A5), "Tea, sardines in oil, onion, ajvar1 " (A6), "A mixture of cereals and dried fruits, tea" (A7). Menu dishes A1-A6 are prescribed by the Educational Institution Nutrition Plan and have been used for a longer period of time, 
while A7 dish was introduced as a trial to demonstrate the method of correcting the menu by introducing new, better ranked dishes based on given criteria(Arsic et al., 2018).

In the first step, the initial decisionmaking matrix is formed, based on the evaluation of all menu dishes according to defined criteria, Table5.

The values of criteria $\mathrm{C} 1-\mathrm{C} 3$ and $\mathrm{C} 9$ were acquired by surveying 15 experts with years of work experience in technological process of menu dishes preparation (restaurant staff in charge of storing, preparation and distribution of food in a restaurant in conditions of normal and unforeseen circumstances). In order to determine the values of $\mathrm{C} 6-\mathrm{C} 8$ criteria, a survey was conducted with 35 restaurant users. The value of $\mathrm{C} 4$ criterion was obtained by analyzing the market and choosing the best price and criteria $\mathrm{C} 5$ by using the data from the existing institutional planning documents, tables with measured caloric values of the menu dishes being evaluated. Variations in the assessments that experts have assigned while evaluating criteria $\mathrm{C} 1$ C3 and C6-C9 are expressed in rough numbers which treat the subjective perception of the experts during assessment. The aggregated values of rough numbers shown in Table 5 were obtained using RNGBM. For example, the aggregated value at the position $\mathrm{A} 1-\mathrm{C} 1$ of the initial decision making matrix (Table 5) was performed using the expression (8).

$$
\begin{aligned}
& \operatorname{RNGBM}^{p, q}\left(R N\left(\phi_{11}^{(1)}\right), R N\left(\phi_{11}^{(2)}\right), \ldots, R N\left(\phi_{11}^{(15)}\right)\right)= \\
& =R N G B M^{p, q}([2.85,3.14],[2.85,3.14], \ldots,[1,3],[2.85,3.14])=\left(\frac{1}{15} \sum_{\substack{i, j=1 \\
i \neq j}}^{15} R N\left(\phi_{1 i}^{p}\right)\left(\prod_{j=1}^{15} R N\left(\phi_{1 j}^{q}\right)\right)^{\frac{1}{14}}\right)^{\frac{1}{p+q}} ; p=q=1 \\
& =R N G B M^{1,1}=\left\{\begin{array}{l}
\underline{\operatorname{Lim}}\left(\phi_{11}\right)=\left(\frac{1}{15}\left(\begin{array}{l}
2.85 \cdot(2.85 \cdot 2.85 \cdot 2.85 \cdot, \ldots, 1 \cdot 2.85)^{1 / 14}+2.85 \cdot(2.85 \cdot 2.85 \cdot 2.85 \cdot, \ldots, 1 \cdot 2.85)^{1 / 14}+, \ldots,+ \\
1 \cdot(2.85 \cdot 2.85 \cdot 2.85 \cdot, \ldots, 3 \cdot 2.85)^{1 / 14}+2.85 \cdot(2.85 \cdot 2.85 \cdot 2.85 \cdot, \ldots, 3 \cdot 1)^{1 / 14}
\end{array}\right)\right)^{1 / 2}=2.707 \\
\overline{\operatorname{Lim}}\left(\phi_{11}\right)=\left(\frac{1}{15}\left(\begin{array}{l}
3.14 \cdot(3.14 \cdot 3.14 \cdot 3.14 \cdot, \ldots, 3 \cdot 3.14)^{1 / 14}+3.14 \cdot(3.14 \cdot 3.14 \cdot 3.14 \cdot, \ldots, 3 \cdot 3.14)^{1 / 14}+, \ldots,+ \\
3 \cdot(3.14 \cdot 3.14 \cdot 3.14 \cdot, \ldots, 4 \cdot 3.14)^{1 / 14}+3.14 \cdot(3.14 \cdot 3.14 \cdot 3.14 \cdot, \ldots, 4 \cdot 3)^{1 / 14}
\end{array}\right)\right)^{1 / 2}=3.238
\end{array}\right. \\
& =R N G B M^{1,1}=[2.707,3.238]
\end{aligned}
$$

\begin{tabular}{|c|c|c|c|c|c|c|c|c|c|}
\hline Alt. & $\mathrm{C} 1$ & $\mathrm{C} 2$ & $\mathrm{C} 3$ & $\mathrm{C} 4$ & C5 & C6 & C7 & $\mathrm{C} 8$ & C9 \\
\hline $\mathrm{A} 1$ & {$[0.001,0.003]$} & {$[0,0.002]$} & {$[0.006,0.015]$} & {$[0,0]$} & {$[0.021,0.027]$} & {$[0.002,0.01]$} & {$[0.003,0.008]$} & {$[0.002,0.018]$} & {$[0.002,0.004]$} \\
\hline $\mathrm{A} 2$ & {$[0.001,0.003]$} & {$[0,0.003]$} & {$[0.004,0.016]$} & {$[0.002,0.004]$} & {$[0.027,0.034]$} & {$[0.001,0.011]$} & {$[0.003,0.008]$} & {$[0.004,0.021]$} & {$[0.002,0.004]$} \\
\hline A3 & {$[0,0.001]$} & {$[0,0.003]$} & {$[0,0.015]$} & {$[0.002,0.005]$} & {$[0.012,0.014]$} & {$[0.003,0.011]$} & {$[0.002,0.008]$} & {$[0.003,0.018]$} & {$[0.003,0.005]$} \\
\hline A4 & {$[0.0 .002]$} & {$[0.001,0.004]$} & {$[0.003,0.013]$} & {$[0.003,0.005]$} & {$[0.022,0.028]$} & {$[0,0.008]$} & {$[0,0.006]$} & {$[0,0.012]$} & {$[0.003,0.005]$} \\
\hline A5 & {$[0.002,0.005]$} & {$[0.002,0.006]$} & {$[0.011,0.025]$} & {$[0.003,0.006]$} & {$[0.019,0.023]$} & {$[0.003,0.012]$} & {$[0.001,0.007]$} & {$[0.002,0.017]$} & {$[0,0.001]$} \\
\hline A6 & {$[0.002,0.005]$} & {$[0.004,0.007]$} & {$[0.012,0.026]$} & {$[0,0.001]$} & {$[0,0]$} & {$[0,0.011]$} & {$[0.001,0.008]$} & {$[0.002,0.019]$} & {$[0,0.001]$} \\
\hline A7 & {$[0.002,0.005]$} & {$[0.004,0.008]$} & {$[0.015,0.028]$} & {$[0.003,0.006]$} & {$[0.009,0.011]$} & {$[0.008,0.015]$} & {$[0.006,0.01]$} & {$[0.009,0.024]$} & {$[0,0.002]$} \\
\hline
\end{tabular}

Table 6. Theoretical assessments matrix

\begin{tabular}{ccccccccccc}
\hline PAi/Criteria & $\mathrm{C} 1$ & $\mathrm{C} 2$ & $\mathrm{C} 3$ & $\mathrm{C} 4$ & $\mathrm{C} 5$ & $\mathrm{C} 6$ & $\mathrm{C} 7$ & $\mathrm{C} 8$ & $\mathrm{C} 9$ & \\
PA1 & {$[0.003,0.005]$} & {$[0.006,0.008]$} & {$[0.017,0.028]$} & {$[0.003,0.006]$} & {$[0.027,0.034]$} & {$[0.011,0.015]$} & {$[0.008,0.010]$} & {$[0.014,0.024]$} & {$[0.003,0.003]$} \\
$\ldots$ & $\ldots$ & $\ldots$ & $\ldots$ & $\ldots$ & $\ldots$ & $\ldots$ & $\ldots$ & $\ldots$ & $\ldots$ & $\ldots$ \\
PA9 & {$[0.003,0.005]$} & {$[0.006,0.008]$} & {$[0.017,0.028]$} & {$[0.003,0.006]$} & {$[0.027,0.034]$} & {$[0.011,0.015]$} & {$[0.008,0.010]$} & {$[0.014,0.024]$} & {$[0.003,0.003]$} \\
\hline
\end{tabular}

Table 7. Real assessments matrix 
Table 8. Total gap matrix

\begin{tabular}{cccccccccc}
\hline Alter. & $\mathrm{C} 1$ & $\mathrm{C} 2$ & $\mathrm{C} 3$ & $\mathrm{C} 4$ & $\mathrm{C} 5$ & $\mathrm{C} 6$ & $\mathrm{C} 7$ & $\mathrm{C} 8$ & $\mathrm{C} 9$ \\
\hline A1 & {$[0.003,0]$} & {$[0.008,0]$} & {$[0.016,0]$} & {$[0.007,0]$} & {$[0.009,0]$} & {$[0.009,0]$} & {$[0.006,0]$} & {$[0.014,0]$} & {$[0.003,0]$} \\
A2 & {$[0.003,0]$} & {$[0.007,0]$} & {$[0.018,0]$} & {$[0.003,0]$} & {$[0,0]$} & {$[0.01,0]$} & {$[0.006,0]$} & {$[0.011,0]$} & {$[0.003,0]$} \\
A3 & {$[0.005,0]$} & {$[0.007,0]$} & {$[0.021,0]$} & {$[0.002,0]$} & {$[0.025,0]$} & {$[0.009,0]$} & {$[0.006,0]$} & {$[0.013,0]$} & {$[0.001,0]$} \\
A4 & {$[0.004,0]$} & {$[0.007,0]$} & {$[0.02,0]$} & {$[0.002,0]$} & {$[0.008,0]$} & {$[0.013,0]$} & {$[0.009,0]$} & {$[0.019,0]$} & {$[0.002,0]$} \\
A5 & {$[0,0]$} & {$[0.005,0]$} & {$[0.007,0]$} & {$[0,0]$} & {$[0.013,0]$} & {$[0.008,0]$} & {$[0.008,0]$} & {$[0.014,0]$} & {$[0.006,0]$} \\
A6 & {$[0,0]$} & {$[0.002,0]$} & {$[0.005,0]$} & {$[0.006,0]$} & {$[0.043,0]$} & {$[0.011,0]$} & {$[0.007,0]$} & {$[0.013,0]$} & {$[0.006,0]$} \\
A7 & {$[0,0]$} & {$[0.002,0]$} & {$[0.002,0]$} & {$[0.001,0]$} & {$[0.03,0]$} & {$[0.003,0]$} & {$[0.003,0]$} & {$[0.005,0]$} & {$[0.006,0]$} \\
\hline
\end{tabular}

The aggregation of the remaining matrix positions is performed in the same way.

In the second step, the preferences of the decision-maker towards alternatives are determined. Bearing in mind that the decision-maker is neutral in terms of alternatives, using the expression (17), the following preferences are obtained

$P_{A_{1}}=P_{A_{2}}=\ldots=P_{A_{9}}=\frac{1}{9}=0.11$

In the third step, using the expression (19), the elements of theoretical assessments matrix are obtained, Table 6

In the fourth step, the elements of real assessments matrix are calculated using the expression (21), Table 7.

In the next step, the calculation of total gap matrix was carried out using the expression (24), Table 8.

By summarizing matrix elements shown in Table 8 , the final values of criterion functions by alternatives are obtained, expression (25). The initial ranks of alternatives are shown in Table 9.

Table 9. Ranks of alternatives

\begin{tabular}{cccc}
\hline Alter. & $\mathrm{Q}_{\mathrm{i}}$ & $\mathrm{Ri}$ & $\mathrm{Rf}$ \\
\hline$A 1$ & 0,076 & 4 & 4 \\
$A 2$ & 0,061 & 3 & $1^{*}$ \\
$A 3$ & 0,09 & 6 & 6 \\
$A 4$ & 0,083 & 5 & 5 \\
$A 5$ & 0,061 & 2 & $1^{*}$ \\
$A 6$ & 0,095 & 7 & 7 \\
$A 7$ & 0,051 & 1 & 1 \\
\hline
\end{tabular}

In the sixth step, dominance index of the first-ranked alternative is determined, expression (26). The values of dominance index (Table 10) represent the advantage of the first-ranked alternative in relation to all other alternatives.

Table 10. Values of dominance index

\begin{tabular}{cc}
\hline Alter. & $\mathrm{A} D, 1-j$ \\
\hline$A 1$ & 0,257 \\
$A 2$ & 0,107 \\
$A 3$ & 0,407 \\
$A 4$ & 0,333 \\
$A 5$ & 0,107 \\
$A 6$ & 0,461 \\
$A 7$ & 0 \\
\hline
\end{tabular}

Dominance index of the first-ranked alternative $\mathrm{A} 7$ in relation to alternative $\mathrm{A} 1$, which is the fourth in ranking, is determined using the expression (26)

$$
A_{D, 1-7}=\frac{Q_{A 7}-Q_{A 1}}{Q_{A 6}}=\frac{0.0755-0.0511}{0.0949}=0.2566
$$

where $Q_{A 7}$ is the criterion function of the first ranked alternative (A7), $Q_{A 6}$ is the criterion function of the alternative that is the last one in ranking (A6), and $Q_{A 1}$ is the criterion function of the alternative with which the first ranked alternative is being compared (A1). After determining dominance index, using the expression (27) dominance threshold is determined, as follows

$$
I_{D}=\frac{m-1}{m^{2}}=\frac{7-1}{7^{2}}=0.122
$$


where $m$ is the total number of alternatives.

Using the expression (28), i.e. by comparing the obtained dominance index from Table 10 with the dominance threshold, the final rank of alternatives (Rf) is obtained, which is shown in Table 9. Presented advantage is not sufficient to favor the firstranked alternative $\mathrm{A} 7$ with certainty based on the results. Therefore, according to conditions in the expression (28), ranks of alternatives A5 and A2 were corrected, and they were assigned a conditional rank marked as $1 *$. The second-ranked and thirdranked alternative A5 and A2 have almost the same values of criterion function so they can be observed as alternatives of identical rank. The final selection of the best menu was carried out through validation of the obtained results with other MCDM models, shown in section 4, which confirmed the initial rank.

\section{DISCUSSION OF RESULTS AND SENSITIVITY ANALYSIS}

The discussion of results was performed through result presentation of three MCDM methods: MAIRCA, MABAC and VIKOR. These methods have been selected since their previous application has shown that they provide stable and reliable results (Pamučar et al., 2018). MAIRCA, MABAC and VIKOR methods were modified using rough numbers. In the second part of the result discussion, sensitivity analysis of BWMR'MAIRCA model was carried out through 27 scenarios. In order to make the final decision on choosing an optimal alternative, it is necessary to evaluate the reliability of results obtained by the initial model. The reliability of results is most often checked by comparing with other MCDM techniques.
Ranking of alternatives by methods used to assess the reliability of results (Table 11) shows that the alternative A7 remained firstranked in all cases.

Table 11. Comparison of alternatives by methods

\begin{tabular}{cccc}
\hline Alter. & $\begin{array}{c}\text { Rough- } \\
\text { MAIRCA }\end{array}$ & $\begin{array}{c}\text { Rough- } \\
\text { MABAC }\end{array}$ & $\begin{array}{c}\text { Rough- } \\
\text { VIKOR }\end{array}$ \\
\hline A1 & 4 & 4 & 4 \\
$A 2$ & 3 & 3 & 2 \\
$A 3$ & 7 & 6 & 7 \\
$A 4$ & 5 & 5 & 5 \\
$A 5$ & 2 & 2 & 3 \\
$A 6$ & 6 & 7 & 6 \\
$A 7$ & 1 & 1 & 1 \\
\hline
\end{tabular}

Since the results of MCDM methods largely depend on the values of weight coefficients of the evaluation criteria, in the following section, sensitivity analysis of the results to the change in weights of criteria is presented. Sometimes ranks of alternatives shift with very small changes in weight coefficients. Therefore, the results of MCDM methods as a rule are followed by the analysis of their sensitivity to these changes. In the following section, sensitivity analysis of ranks of alternatives to the changes in weight coefficients of the criteria, which was carried out through 27 scenarios is presented (Table 12).

Table 12. Scenarios of sensitivity analysis

\begin{tabular}{cc}
\hline Weights of criteria & \multicolumn{1}{c}{ Ranking } \\
\hline$w_{c 11}=1.25 \times w_{c 11(\text { old })} ;$ & $\mathrm{A} 7>\mathrm{A} 5>\mathrm{A} 2>\mathrm{A} 1>\mathrm{A} 4>\mathrm{A} 3>\mathrm{A} 6$ \\
$w_{c 12}=1.25 \times w_{c 12(\text { old })} ;$ & $\mathrm{A} 7>\mathrm{A} 5>\mathrm{A} 2>\mathrm{A} 1>\mathrm{A} 4>\mathrm{A} 3>\mathrm{A} 6$ \\
$\ldots$ & $\ldots$ \\
$w_{c 19}=1.25 \times w_{c 19(\text { old })} ;$ & $\mathrm{A} 7>\mathrm{A} 2>\mathrm{A} 5>\mathrm{A} 1>\mathrm{A} 4>\mathrm{A} 3>\mathrm{A} 6$ \\
\hline$w_{c 11}=1.5 \times w_{c 11(\text { old })} ;$ & $\mathrm{A} 7>\mathrm{A} 5>\mathrm{A} 2>\mathrm{A} 1>\mathrm{A} 4>\mathrm{A} 3>\mathrm{A} 6$ \\
$w_{c 12}=1.5 \times w_{c 12(\text { old })} ;$ & $\mathrm{A} 7>\mathrm{A} 5>\mathrm{A} 2>\mathrm{A} 1>\mathrm{A} 4>\mathrm{A} 3>\mathrm{A} 6$ \\
$\ldots$ & $\ldots$ \\
$w_{c 19}=1.5 \times w_{c 19(\text { old })} ;$ & $\mathrm{A} 7>\mathrm{A} 2>\mathrm{A} 5>\mathrm{A} 1>\mathrm{A} 4>\mathrm{A} 3>\mathrm{A} 6$ \\
\hline$w_{c 11}=1.75 \times w_{c 11(\text { old })} ;$ & $\mathrm{A} 7>\mathrm{A} 5>\mathrm{A} 2>\mathrm{A} 1>\mathrm{A} 4>\mathrm{A} 3>\mathrm{A} 6$ \\
$w_{c 12}=1.75 \times w_{c 12(\text { old })} ;$ & $\mathrm{A} 7>\mathrm{A} 5>\mathrm{A} 2>\mathrm{A} 1>\mathrm{A} 4>\mathrm{A} 3>\mathrm{A} 6$ \\
$\ldots$ & \\
$w_{c 19}=1.75 \times w_{c 19(\text { old })} ;$ & $\mathrm{A} 7>\mathrm{A} 2>\mathrm{A} 5>\mathrm{A} 1>\mathrm{A} 4>\mathrm{A} 3>\mathrm{A} 6$ \\
\hline
\end{tabular}


Scenarios of sensitivity analysis are grouped into three stages. Within each stage of sensitivity analysis, weight coefficients of the criteria were increased by $25 \%, 50 \%$ and $75 \%$ respectively. In each of the 27 scenarios, within stage, one criterion is favored for which the weight coefficient is increased by specified values.

The results (Table 12) show that assigning different weights to criteria through scenarios leads to a change in ranks of alternatives, which confirms that the model is sensitive to changes in weight coefficients. By comparing the first-ranked alternatives (A7, A5 and A2) in scenarios 1-27 with the initial ranks from Table 9, it is observed that the ranks of the first-ranked alternatives are confirmed. By analyzing the ranks through 27 scenarios, it is also noticed that the alternative A7 retained its rank in 25 scenarios, while in one scenario it was second-ranked and in one third-ranked. The second-ranked alternative A5 kept its rank in 17 scenarios while in 10 scenarios it was third-ranked. The third-ranked alternative A2 kept its rank in 15 scenarios, while in 2 scenarios it was first-ranked and in 8 scenarios second-ranked. During the change in weights of criteria through scenarios, there were minor changes in ranks of the remaining alternatives, Fig. 1.

It can be concluded that ranking changes

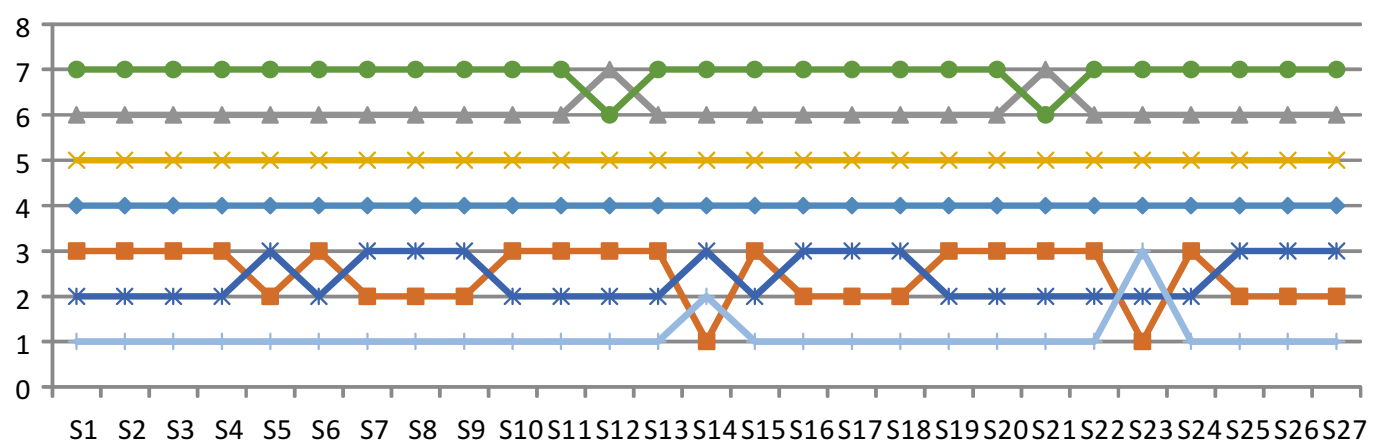

Figure 1. Change of ranks through scenarios 1-27 were not drastic, which is confirmed by the correlation of ranks through scenarios. Spearman's rank correlation coefficient (SRCCC) is a useful and important indicator for determining the connection between results obtained by different methods (Stanujkić \& Karabašević, 2018). In addition, SRCC is suitable for application in cases of ordinal variables or range variables, as it is presented in this study. In this research, using SRCC the statistical significance of difference between ranks obtained by different methods is defined. SRCC values were acquired by comparing the initial rank of BWM-R'MAIRCA model (Table 9) with ranks obtained through scenarios (Table 12). The results of rank comparison using SRCC are shown in Table 13.

By analyzing the results (Table 13) it can be concluded that there is a high correlation of ranks, since the mean value of SRCC through all scenarios is 0.975, Fig. 2.

Based on the presented analysis it can be concluded that there is a satisfactory closeness of ranks and that the proposed rank is confirmed and credible. It can be also infered that the approach based on rough numbers is successfully exploiting the uncertainties that arise in group decisionmaking. 
Table 13. Correlation of 27 scenario ranks

\begin{tabular}{cccccc}
\hline Scenario & SRCC & Scenario & SRCC & Scenario & SRCC \\
\hline S1 & 1,000 & S10 & 1,000 & S19 & 1,000 \\
S2 & 1,000 & S11 & 1,000 & S20 & 1,000 \\
S3 & 1,000 & S12 & 0,964 & S21 & 0,964 \\
S4 & 1,000 & S13 & 1,000 & S22 & 1,000 \\
S5 & 0,964 & S14 & 0,893 & S23 & 0,857 \\
S6 & 1,000 & S15 & 1,000 & S24 & 1,000 \\
S7 & 0,964 & S16 & 0,964 & S25 & 0,964 \\
S8 & 0,964 & S17 & 0,964 & S26 & 0,964 \\
S9 & 0,964 & S18 & 0,964 & S27 & 0,964 \\
\hline
\end{tabular}

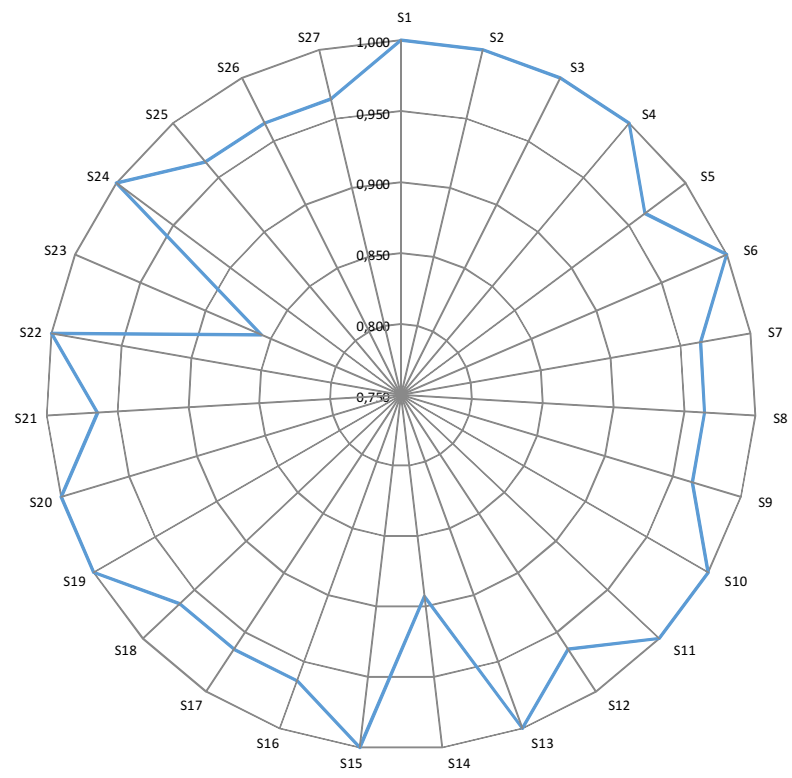

Figure 2. Spearman's correlation coefficient in 27 scenarios

\section{CONCLUSION}

The evaluation of menu is based on an objective and precise understanding of relevant factors that affect the satisfaction of users and restaurant employees.

User satisfaction is reflected in sensory perception and subjective feeling during and after the meal, while employee satisfaction reflects the synthesis of various impressions such as personal income, working conditions, work atmosphere and other feedback effects that imply user satisfaction. In a stimulating work environment, users and employees of a restaurant stimulate each other by raising the aspiration level over a longer period of time (Arsic, 2014).

Previous researches in this area have been based mainly on matrix formats with four and eight fields and did not significantly exploit numerous advantages provided by multi-criteria decision-making models and decision support tools.

BWM and R'MAIRCA-based approach allows the aggregation of a large number of relevant criteria, the elimination of subjective assessment uncertainty about the importance of expert criteria from various areas related to diet (nutrition, food technology, nutrition organization, quality of life) and precise positioning of dishes according to value rank obtained by the 
evaluation. During the testing of the introduced approach 9 relevant experts have influenced on forming the weight coefficients of three groups of criteria: 1.group of criteria related to the subscribers (C6-C8) was evaluated by 35 users; 2.group of criteria related to food preparation $(\mathrm{C} 1-\mathrm{C} 3$ and C9) was evaluated by 15 experts involved in food preparation process; 3.group consists of criteria related to the price of fresh foods required for food preparation (C4) acquired from market analysis and the caloric value of a ready meal (C5) measured in a renowned state institution. In this study, a precise evaluation of the existing menu was made and the possibility of introducing a new dish in the menu (A7) was tested based on user request.

The contribution of the study can be seen through several segments. First, the increases of universality of the analysis by including criteria that do not have a dominant commercial character and are directed to reliability. Second, the improvement of methodology for determining the weights of criteria by eliminating subjectivity and imprecisions. Third presents a prioritization of criteria and a formation of a model that enables an objective and scientifically based approach in menu evaluation. Fourth represents a new BWM-R'MAIRCA model for multi-criteria menu evaluation.

The application of the model showed that the potential meal is first-ranked, based on which a decision can be made about exceptional suitability of this meal when forming a new menu. The approach can be very effectively applied reversibly, when it is necessary to form a menu based on the defined effects that nutrition should manifest on the target group of subscribers (favoring the quantity of nutrients and their digestibility, elan for physical work after the meal, preparation in unforeseen circumstances, etc.) especially in restaurants for collective nutrition of students, athletes, security forces and convalescents, so future research should be aimed in that direction. In educational terms, the approach helps decision makers to better understand the complexity of the process of identifying the relevant criteria, dish evaluation and creating an optimal menu in given time, space, social, economic and other circumstances.

\section{References}

Arsic, S. (2014). Possibilities for improving the food system at the Military Academy - the economic aspect. Military Technical Courier, 4, 168-186.

Arsic, S., Pamucar, D., \& Suknovic, M. (2018). Determining the weights of criteria in menu evaluation using Best-Worst method. In Proceedings of XVI International Symposium Doing Business in the Digital Age: Challenges, Approaches And Solutions, SymOrg 2018. University of Belgrade Faculty of Organizational Sciences. Zlatibor. 292-297.

Badi, I., \& Ballem, M. (2018). Supplier Selection using rough BWM-MAIRCA model: A case study in pharmaceutical supplying in Libya. Decision Making: Applications in Management and Engineering, 1 (2), 15-32.

Bayou, M.E., \& Bennett, L.B. (1992). Profitability analysis for table-service restaurants. Cornell Hotel and Restaurant Administration Quarterly, 33(2), 49-45.

Chatterjee, K., Pamučar, D., \& Zavadskas, E.K. (2018). Evaluating the performance of suppliers based on using the R'AMATELMAIRCA method for green supply chain implementation in electronics industry. 


\title{
ОЦЕЊИВАЊЕ MЕНИЈА БАЗИРАНО НА "ROUGН MAIRCA" И "ВW" МЕТОДАМА
}

\author{
Славиша Н. Арсић, Драган Памучар, Милија Сукновић и Миљојко Јаношевић
}

\section{Извод}

Евалуација оброка представља основну активност у структурирању менија, што омогућава оптимално коришћење ресурса како би се у потпуности задовољила очекивања корисника и менаџмента ресторана.

Ова студија представља нови приступ у оцењивању менија коришћењем методе Мулти Атрибутиве Идеалне-Реалне Компаративе Анализе (“MAIRCA”), модификоване применом грубих бројева у решавању непрецизности у групном одлучивању и методе Најбољи-Најгори (“BWM”) за одређивање вредности интервала тежинских коефицијената који објективизују недоследности у стручној процени.

Модел је успешно тестиран на јеловнику ресторана за заједничку прехрану, где је спроведена процена шест постојећих јела за доручак и ново јело које би требало да замени најлошије јело.

Валидација модела је извршена упоређивањем резултата добијених применом "МАВАС” и "VIKOR" метода, чиме је потврђена висока поузданост. Валидиране вриедности су разматране у анализи осетљивости, кроз 27 сценарија са променом вредности тежинских коефицијената, чиме је показана висока корелација добијених рангова и потврда веродостојности добијених вредности.

Кључне речи: оцена менија, менаџмент ресторана, "rough MAIRCA", "BWM", колективна исхрана

Journal of Cleaner Production, 184, 101-129. Inc. Lansing, MI

Cohen, E., Mesika, R., \& Schwartz, Z. LeBruto, S., Ashley, R., \& Quain, W. (1998). A multidimensional approach to (1995). Menu Engineering: a model menu sales mix analysis. Praxis, 2(1), 130- including labor. Hospitality Review, 13(1), 144. 41-50.

Gigović, Lj., Pamučar, D., Bajić, Z., \& Milićević, M. (2016). The combination of expert judgment and GIS-MAIRCA analysis for the selection of sites for ammunition depot. Sustainability, 8(4), 1-30.

Liu, Y., \& Lv, Y. (2014). A Multiple Attribute Decision Making Method With Interval Rough Numbers Based on the Possibility. In Proceedings of the 10th

Hayes, D.K., \& Huffman, L. (1985). Menu analysis: a better way. Cornell Hospitality Quarterly, 25(4), 64-70.

International Conference on Natural Computation (ICNC '14). IEEE. Xiamen. China, 407-411.

McCall, M., \& Lyn, A. (2008). The effects

Horton, B.W. (2001). The effect of labor and menu category on menu classifications. Hospitality Review, 19(2), 35-46.

Kasawana, M.L., \& Smith, D.J. (1982). Menu engineering. Hospitality Publications of restaurant menu item descriptions on perceptions of quality, price, and purchase intention. Journal of food service Business Research, 11(4), 439-445.

Miller, J.E. (1980). Menu Pricing and 
Strategy. CBI Publishing. Boston.

Miller, J.E. (1987). Menu Pricing and Strategy. Reinhold Van Nostrand. New York.

Morrison, P. (1996). Menu engineering in upscale restaurants. International Journal of Contemporery Hospitality Management, 8(4), 17-24.

Nunić, Z. (2018). Evaluation and selection of the PVC carpentry Manufacturer using the FUCOM-MABAC model, Operational Research in Engineering Sciences: Theory and Applications, 1(1), 1328.

Pamučar, D., Petrović I., \& Ćirović, G. (2018). Modification of the Best-Worst and MABAC methods: A novel approach based on interval-valued fuzzy-rough numbers. Expert systems with applications, 91, 89106.

Pamučar, D., Mihajlović, M., Obradović, R., \& Atanasković, P. (2017). Novel approach to group multi-criteria decision making based on interval rough numbers: Hybrid DEMATEL-ANP-MAIRCA model. Expert Systems with Applications, 88, 58-80.

Pamučar, D., Vasin, LJ., \& Lukovac, V. (2014). Selection of railway level crossing for investing in security equipment using hybrid DEMATEL-MAIRCA. In: Proceedings of XVI International Scientificexpert Conference on Railway, Railcon. University of Niš. Niš. 89-92.

Pavesic, D. (1983). Cost-margin analysis: a third approach to menu pricing and design. International Journal of Hospitality Management, 2(3), 127-134.

Pawlak, Z. (1982). Rough sets. International Journal of Computer \& Information Sciences, 11(5), 341-356.

Rezaei, J. (2016). Best-worst multicriteria decision-making method: Some properties and a linear model. Omega, 64, 126-130.
Rezaei, J. (2015). Best-worst multicriteria decision-making method. Omega, 53, 49-57.

Stanujkić, D., \& Karabašević, D. (2018). An extension of the WASPAS method for decision-making problems with intuitionistic fuzzy numbers: a case of website evaluation. Operational Research in Engineering Sciences: Theory and Applications, 1(1), 2939.

Taylor, J., \& Brown, D. (2007). Menu analysis: a review of techniques and approaches. Hospitality Review, 25(2), 7482.

Taylor, J., Reynolds, D., \& Brown,D. (2009). Multi-factor menu analysis using data envelopment analysis. International Journal of Contemporary Hospitality Management, 21(2),213-225.

Tom, M., \& Annaraud, K. (2017). A fuzzy multi-criteria decision making model for menu engineering. 2017 IEEE International Conference on Fuzzy Systems (FUZZIEEE), 1-6.

Vasiljevic, M., Fazlollahtabar, H., Stevic, Z., Veskovic, S. (2018). A rough multicriteria approach for evaluation of the supplier criteria in automotive industry. Decision Making: Applications in Management and Engineering, 1(1), 82-96.

Zhai, L.Y., Khoo, L.P., \& Zhong, Z.W. (2008). A rough set enhanced fuzzy approach to quality function deployment. International Journal of Advanced Manufacturing Technology, 37(5-6), 613-624.

Zhu, B., Xu, Z.S., \& Xia, M.M. (2012). Hesitant fuzzy geometric Bonferroni means. Information Sciences, 205, 72-85.

Zhu, G.N., Hu, J., Qi, J., Gu, C.C., Peng, J.H. (2015). An integrated AHP and VIKOR for design concept evaluation based on rough number. Advanced Engineering Informatics, 29, 408-418. 